\section{The Effects of Polyhedrons in Developing Three Dimensional Form Perception}

Rabia Akgül ${ }^{1}$, ORCID: 0000-0002-2323-7495

Hasan Begeç2, ORCID: 0000-0002-0137-2848

\section{Keywords}

polyhedrons, basic design education, computational design

\section{Article Information}

\section{Abstract}

This study was conducted to determine whether it is possible to combine the traditional education model and computational design approach to improve the three dimensional morphology. In this study, many national and international publications related to the research subject were examined and a theoretical framework was established and a workshop was conducted with 42 students who received architectural basic design education. In order to evaluate the workshop, a questionnaire was collected with the students who participated in the workshop. The data obtained from the survey were evaluated with the statistical evaluation program (SPSS). In the study, students' individual gains in the workshop process; shape space perception development $82.9 \%$, three-dimensional thinking skills $92.7 \%$, self-confidence and decision-making ability to use $39 \%, 73.2 \%$ to have the chance to try and error, $95.1 \%$ of learning skills, while they were found to have acquired. Students' group work gains; $87.2 \%$, the decision-making experience $84.6 \%$, the discussion and exchange of ideas $79.5 \%$. When the design models learned by the students are examined; understanding of the number of edges, corners and surfaces of smooth four sides was determined as $82.1 \%$, and the number of edges, corners and surfaces of the cube was $79.5 \%$. In this study; as a formatting method and computational design has achieved a great deal of success in terms of providing basic gains. Polyhedrons have been identified as a suitable design object in order to improve the three-dimensional morphology and to combine the traditional education model with computational design approach.
Received: 15.11.2019

Accepted: 13.01 .2020

Available Online: 28.01.2020

Article Info: This study was produced from the master's dissertation, titled "An Experimental Study on the Effects of Polyhedrons on Three-Dimentional Shaping in Architectural Basic Education" at the Department of Architecture, Dokuz Eylül University.

1. Department of Architecture, Dokuz Eylül University, İzmir, Turkey,rabiakgul@gmail.com

2. Department of Architecture, Dokuz Eylül University, İzmir, Turkey, hasan.begec@deu.edu.tr 


\section{Üç Boyutlu Biçim Algısını Geliştirmede Polihedronların Etkileri}

Rabia Akgül11, ORCID: 0000-0002-2323-7495

Hasan Begeç2, ORCID: 0000-0002-0137-2848

$\ddot{\mathrm{O} z}$

Bu araştırma, üç boyutlu biçim bilgisini geliştirmek için geleneksel eğitim modeliyle hesaplamalı tasarım yaklaşımını birleştirmenin mümkün olup olmayacağını belirlemek amacıyla yapılmıştır. Çalışmada, araştırma konusuyla ilgili ulusal ve uluslararası birçok yayın incelenerek kuramsal çerçevenin oluşturulması sağlanmış ve mimarlık temel tasarım eğitimi almış 42 öğrenci ile atölye çalışması gerçekleştirilmiştir. Atölye çalışmasının değerlendirilmesinin yapılabilmesi için atölyeye katılan öğrencilerle anket yapılarak veri toplanmıştır. Anket çalışması ile elde edilen veriler istatistik değerlendirme programı (SPSS) ile değerlendirilmiştir. Çalışmada, öğrencilerin atölye sürecinde bireysel kazanımlar olarak; \%82,9’unun şekil uzay alg1sı gelişimi, \%92,7'sinin üç boyutlu düşünme becerisi, \%39'unun Özgüven ve karar verme yetisini kullanma, \%73,2'sinin deneyip yanılma şansına sahip olma, \%95,1'inin yaparken öğrenme becerisi edindikleri tespit edilmiştir. Öğrencilerin grup çalışması kazanımları olarak \%87,2'si iş bölümünü gerçekleştirebilme, \%84,6's1 birlikte karar verme deneyimi, \%79,5’ini tartışma, fikir alışverişi ortamında öğrenme, gibi kazanımlar edindikleri tespit edilmiştir. Öğrencilerin öğrendikleri tasarım modelleri incelendiğinde; \%82,1’inin düzgün dört yüzlünün kenar, köşe ve yüzey sayılarının kavranması, \%79,5’inin küpün kenar, köşe ve yüzey sayılarını kavradıkları tespit edilmiştir. Çalışma; bir biçimlendirme yöntemi olarak ve hesaplamalı tasarımın temel kazanımlarını sağlaması bakımından büyük oranda başarı sağlamıştır. Üç boyutlu biçim bilgisini geliştirmek ve geleneksel eğitim modeliyle hesaplamalı tasarım yaklaşımını birleştirmede polihedronların, uygun bir tasarım nesnesi olduğu belirlenmiştir.

\section{Anahtar Sözcükler}

polihedronlar, temel tasarım eğitimi, hesaplamalı tasarım

Makale Bilgileri

\section{Alınd1: 15.11.2019}

Kabul Edildi: 13.01.2020

Erişilebilirlik: 28.01.2020

Makale Bilgisi: Bu çalışma, yazarın Dokuz Eylül Üniversitesi, Mimarlık Bölümünde yapmış olduğu, "Mimarlık Temel Eğitiminde, Polihedronların Üç Boyutlu Biçimlendirmeye Etkileri Üzerine Deneysel Bir Çalışma” isimli yüksek lisans tezinden üretilmiştir.

1. Mimarlık Bölümü, Dokuz Eylül Üniversitesi, İzmir, Türkiye, rabiakgul@gmail.com

2. Mimarlık Bölümü, Dokuz Eylül Üniversitesi, İzmir, Türkiye, hasan.begec@deu.edu.tr 


\section{GİRİS (INTRODUCTION)}

Değişen, devinen, gelişen dünya düzeniyle birlikte hem öğrenci profili, hem de buna bağl1 olarak eğitim öğretim yaklaşımları da değişmekte, yenilenmektedir. Özellikle mimarlık gibi tasarım içerikli bir disiplinin eğitim biçimi çağa ayak uydurmak durumundadır. Mimarlığın doğasında bulunan, her yeni tasarım problemine kendine özgü çözüm geliştirme gereksinimi, eğitime de farklı problem tanımları ve çözüm biçimleri olarak yansımaktadır. Son yüz yılda mimarlık eğitimindeki uygulamaya baktığımızda Beaux Art ekolünün eskiz ve yaparak öğrenme temelli yaklaşımı ve Bauhaus okulunun yaratıcılığı ön plana çıkaran, şartlanmışlıkları yıkmayı hedefleyen, malzemeyi tanımayı önemseyen, sanat ve tekniği birleştiren yaklaşımı günümüzün temel tasarım eğitiminin temel taşları olduğunu görebiliriz. Günümüzde ise gelişen teknoloji ile birlikte dijital dünya ile iç içe bir nesil her y1l kalabalık gruplar halinde mimarlık eğitimine dâhil olmaktadır. Geleneksel temel tasarım eğitim modeli içerisindeki öğrenci, temel eğitim sonrası kaçınılmaz olarak dijital tasarım araçlarını kullanmaktadır. Hatta bu dijitalleşme günümüzde tasarım okullarında eğitim müfredatına da girmeye başlamıştır.

Mimarlık ürünlerinin üç boyutlu biçim çeşitleri olduğu gerçeğinden yola çıkıldığında mimar adayı bir tasarımcı, bir biçimlendiricidir. Biçimlendiricinin zihin - üç boyutlu biçim algısı - yaparak öğrenme koordinasyonunun kurulması gerekmektedir. Üç boyutlu biçim oluşturmada dijital ortamın sunduğu alternatifler, tasarımcının biçim üretme olasılıklarını artırmaktadır. Temel tasarım düzeyinde yapılan bilgisayar destekli örnek çalışmalara bakıldığında; "Computation" kelime kökünden gelen Türkçeye "Hesaplamalı" olarak çevrilen, latince kökeninde ise "bir şeyleri çok net anlama ve her şeyi aynı anda düşünerek yapma" anlamındaki tasarım yaklaşımı görülmektedir (Yalınay, 2012: 25).

Bu çalışma, üç boyutlu biçim bilgisini geliştirmek için izlenecek bir yöntemle, geleneksel eğitim modeliyle hesaplamalı tasarım yaklaşımını birleştirmek mümkün müdür? sorusuna cevap aramaktadır. Bu bağlamda çalışmanın amacı mimarlık temel tasarım eğitiminde öğrencilerin üç boyutlu biçim algısını geliştirecek ve hesaplamalı tasarıma geçişe altlık oluşturabilecek bir biçimlendirme yöntemini denemektir. Hesaplamalı tasarıma geçmeden önce temel biçim algısının oluşturulmasının gerekli olduğundan hareketle noktadan poligona, poligondan polihedrona geçen bir akış ile temel biçim algisının iki boyutta ve üç boyutta oluşturulacağ1 düşünülmektedir. $\mathrm{Bu}$ nedenle denenecek biçimlendirme yönteminin nesnesi olarak "Temel Polihedronlar" belirlenmiştir. 
$\mathrm{Bu}$ araştırma konusuyla ilgili ulusal ve uluslararası birçok yayın incelenerek çalışmanın kuramsal çerçevesinin oluşturulmasındaki temel eğitimde hesaplamalı tasarım yaklaşımları ve temel polihedron bilgisinin verildiği bölümler oluşturulmuştur. Çalışmanın amacına yönelik olarak temel tasarım dersini almış birinci sınıf öğrencileri üzerinde bir uygulama gerçekleştirilmiştir. Bu uygulama kendi içerisinde Armstrong'un bir zeka kullanımından diğerine geçiş için önerdiği tanımlama, deneyimleme, sorgulama aşamalarından oluşmaktadır (Armstrong, 2009:112). Tanımlama aşamasında yapılan literatür taraması ve çizim ve maket üretimleri eşliğinde kavramsal bilgi verilmektedir. Deneyimleme aşamasında kavramsal bilginin içselleştirilmesi ve grup çalışması yapılarak boşlukta hacimsel örgütlenmelerin yapılması istenmektedir. Sorgulama aşamasında ise öğrencilerin kazanımların ölçülmesine yönelik anket yapılmıştır. Anket verileri SPSS 16 istatistiksel veri analiz programı ile incelenerek yorumlanmıştır.

\section{TEMEL EĞİTIMMDE HESAPLAMALI TASARIM YAKLAŞIMLARI (COMPUTATIONAL DESIGN APPROACHES IN BASIC EDUCATION)}

Dijital çăg olarak adlandırabileceğimiz günümüzde, bilgisayar teknolojisi insan hayatının her alanında kullanılmaktadır. Mimarlık alanında ise Autocad, Archicad, Revit, Rhino gibi programların kullanılmasıyla tasarım sürecine hız kazandırılmakta, bu programlardan yardım alınarak çizim yapılmaktadır. Bunun yanında mimarlık eğitiminde birçok öğretim elemanı, derslerinde Autocad, Archicad, Revit Rhino gibi programların kullanılmasını sağlayarak, öğrencilerin mesleki yaşamlarında yeniçağa adapte olabilmesini kolaylaştırmaya çalışmaktadırlar. Yıldız Teknik Üniversitesi, Maltepe Üniversitesi ve Bilgi Üniversitesi gibi baz1 üniversitelerde bu tarz programların kullanımı öğrencilere mimarlık eğitimlerinin ilk senesinde verilmekte buna paralel hesaplamalı tasarım yaklaşımıyla temel eğitim çalışmaları yapılmaktadır.

Hesaplamalı Tasarım yaklaşımının ingilizce karşıllğ̣ olan Computation kelimesinin etimolojik kökenine baktığımızda Latince "Computare” den geldiğini görürüz. Kökündeki 'com' beraber, ile (with) anlamına gelirken putare’ ise açıklığa kavuşturmak (clear up), yerli yerine oturtmak (settle), hesaba katmak/hesaplaşmak (reckon) anlamlarına gelir; yani computare beraber açığa kavuşturmak, yerli yerine oturtmak ve hesaba katmak anlamlarına gelmektedir (URL 1).

Computation kelimesi etimolojik bilgisi dışında matematiksel, sayısal çağrışımlarıyla da ele alınmaktadır. Matematik Yunanca' daki mathemata dan gelir. Kelimeyi oluşturan manthanein öğrenmek anlamına gelirken, mathesis ise öğretmek anlamına gelir, yani hem öğrenilebilir hem öğretilebilir anlamına gelmektedir (URL 2).

Hesaplamalı tasarım, 1960'lardan itibaren mimarlık ve bilimsellik ilişkisini kuran söylemlerle görünür olan bir araştırma kültüründen beslenerek gelişmiş bir tasarım yaklaşımıdır. Hesaplamalı tasarım kavramının kuramsal temeline bakıldığında, dijital platformlardan bağımsız, bilgisayardan daha önce yaparak öğrenme, deneme yanılma, aynı anda birçok şeyi düşünme ve tasarımın gerekçelendirilmesi gibi temellere dayandığı görülmektedir.

Temelinde matematiksel ilişki ve geometrik tekrar gibi sayısal ilkeler olan hesaplamalı tasarım, günümüzde dijital teknoloji ile daha farklı bir mecrada, bilgisayar ortamında daha fazla ve daha kolay uygulama imkanı bulmaktadır. Bu noktada hesaplamalı tasarımı günümüzdeki, bilgisayar 
ortamında kullanılmakta olan mimari program bilgisi ve bu programlar ile tasarımın gerçekleştirilmesi olarak algılamamak gerekmektedir. Bu bağlamda, hesaplamalı tasarım, geleneksel temel tasarım eğitiminde geometri-biçim bilgisi ve geometriye dayalı biçimlenmede matematiksel ilişkilere dayalı tasarım olarak düşünülebilir.

Tasarımda hesaplamalı bakış açısının sayısal teknolojiden bağımsız olarak ortaya çıktığı biloisi, güncel çalışmalarda hesaplamalı tasarım kuramı inşasında kullanılmaktadır (Beşlioğlu, 2013:88). Mimarlık temel eğitim düzeyinde hesaplamalı tasarım yaklaşımı ile bilgisayardan bağımsız biçim üretimi yapmak için yola çıkıldığında Türkiye'de ki ilk hesaplamalı tasarım çalışmalarından biri olarak Beşlioğlu' nun İlhan Koman'ın geliştirilebilir biçim serileri çalışmalarını değerlendirdiği görülmektedir.

İlhan Koman bilimsel kavramlar ve sanat arasındaki ilişkiyi yorumlarken kendi çalışmasının da bilimsel çalışmalar gibi ucu açık ve geliştirilebilir olduğunu dile getirmiştir. Sanatçının bilimsel yaklaşımlarla kurduğu ilişki özellikle 1970 sonrası eserlerinde ele aldığı $\pi$, Çokyüzlüler, Sonsuzluk, Moebius gibi kavramlarda da açıç̧a okunabilmektedir (Beşlioğlu, 20130:92) (Şekil 1).

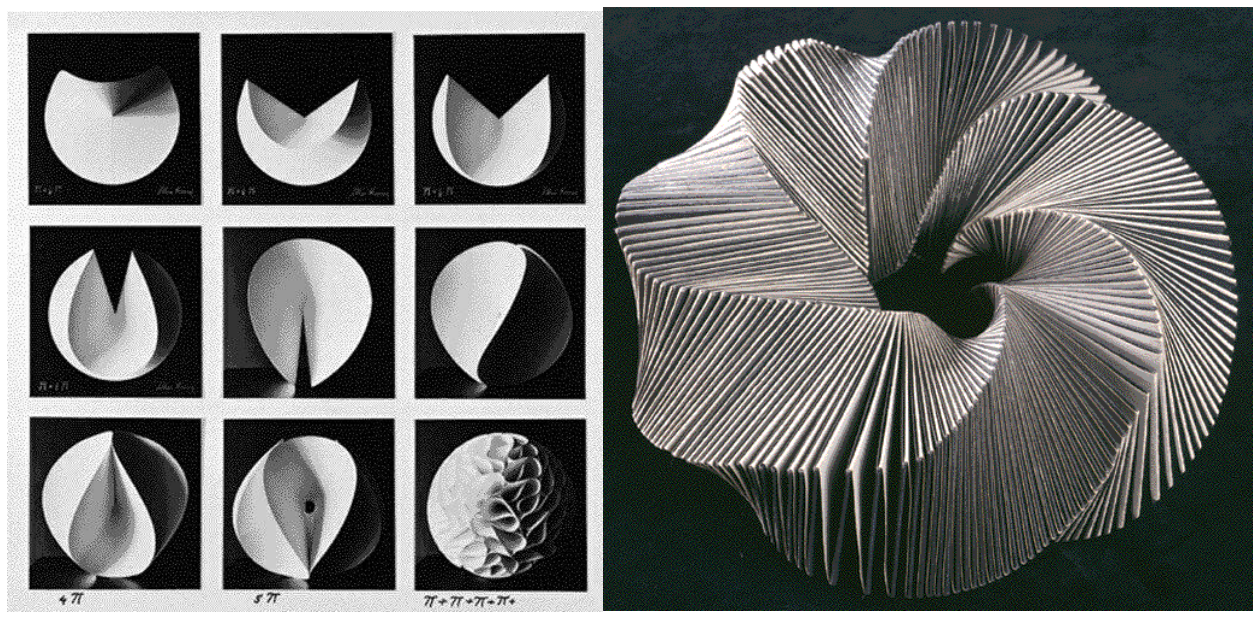

Şekil 1. İlhan Koman, Pi serisi ve Mobius Band1 (URL 3-URL 4)

Koman'ın biçim çalışmalarından, katlandığında minimum hacmin elde edilme özelliğinden dolayı uzay uygulamalarında kullanılabileceğini önerdiği esnek çokyüzlüler, patentini aldığı bir matematik buluş olarak kabul edilmiştir (Beşlioğlu, 2013:91) (Şekil 2).

Koman, $\pi+\pi+\pi+\pi+\cdots$ Dizisindeki yaklaşımını anlattığ1 yazı da sonsuz sayıda $\pi$ nin bir küre oluşturabileceğini, bunun küreye yeni bir tanım getirebileceğini belirtmektedir (Koman,1983:78).

İhan Koman sanat çalışmalarında biçimle ilgili yaklaşımını şu sözlerle anlatmıştır: "Form sorunlarının her zaman yeni bir çözümü olduğunu söylemek istiyorum, benim üzerinde çalıştığım da formdur"(Koman, 1983:78). Form dizilerindeki yaklaşımlarında ele aldığı sorunsal, biçimi içeren bir soru üzerine kurgulanmıştır. Bu sorunun çözüm süreci, sonuç ürünün biçimsel karakterini betimlemek üzerine işlemez, biçimi üretecek sorunun çözümü sürecin tasarlanmasını gerektiren bir tasarım aşamasıdır. 

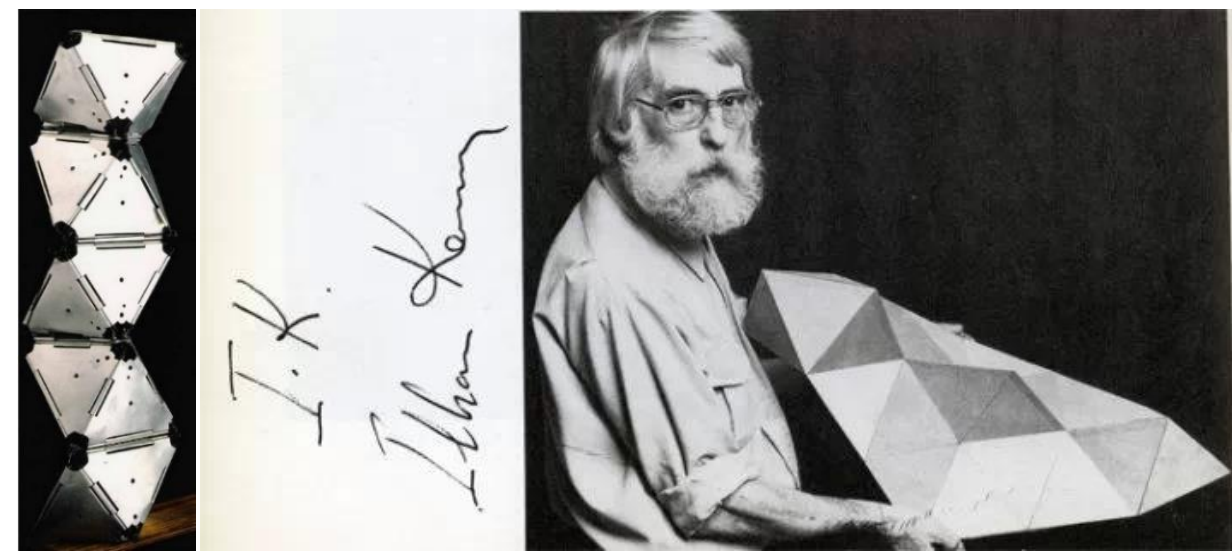

Şekil 2. İlhan Koman ve Esnek Çokyüzlüler (Ataseven, 2011)

Koman'ın geliştirilebilir biçim çalışmalarının açtığı tartışmalar, sürece atfedilen önem, biçimin ilişkisel ve üretken bir sürecin olası sonuçları olarak oluşması ve bununla ilişkili olarak ucu açık bir biçim üretim sürecinde yaratıcı öznenin değişen rolü açılarından hesaplamalı tasarım tartışmaları ile kesişmektedir (Beşlioğlu, 2013:95). Genel kanı biçimin çoğul ve üretken bir kavrayışla tasarlanmasının sayısal ortamın bir potansiyeli olduğu yönündedir. "İlhan Koman'ın biçim serileri ile ortaya konulan yaklaşımı, sayısal teknolojilerin desteğiyle parametrik bir tasarım sürecini önermemekle birlikte Koman'ın geliştirilebilir biçim serileri hesaplamalı yaklaşımın bir örneğidir (Beşlioğlu, 2013:95)".

\section{TEMEL POLİHEDRON BİLGİSİ (BASIC POLYHEDRON INFORMATION)}

Temel polihedronların yapısı doğanın biçimlenme temellerine dayanmaktadır. Temel polihedronlar, kimyasal yapı taşlarında, tek hücreli canlıların yapısında, cansız doğanın kristal biçimlerinde karşımıza çıkmaktadır (Yurtsever, 2008:152). Yapay biçimlendirme örnekleri üzerinden baktığımızda, temel polihedronların mimari, heykel gibi üç boyutlu biçimler üreten disiplinlerde kullanıldığı görülmektedir. Polihedral yapıların çağlar boyunca bilim adamları, sanatçılar ve filozoflarca çeşitli amaçlarla incelendiği bilinmektedir. Üç boyutlu türeyebilen, soyutlayan, temsil eden, bir şeyin yerine geçmeye çalışan, tasarımın önemli ortaklarından biri olan matematiksel biçimler; yani Temel Polihedronlar'ın sayısal tabanlı tasarım eğitimi temellerinde kullanıldığı, tasarı geometri gibi derslerin müfredatında yer aldığı görülmektedir.

Poly, Türkçe de "çoklu” anlamına gelen kelime Yunanca "polus" dan türemiştir (Gausa, Guallart, Müller, Soriano, Porras, \& Morales, 2003:47). Polyhedron'un ise Türkçe literatürde, çokyüzlü olarak karşılığını bulduğu görülmektedir. Düzgün çokyüzlüler (polihedronlar), platonik katılar olarak da adlandırılmaktadır. Düzgün çokyüzlüler, mükemmel simetriye sahip cisimler olup M.Ö. 4. yy. da ilk kez sınıflamasını yapan Platon’un anısına bu ismi almışlardır (Şekil 3). 


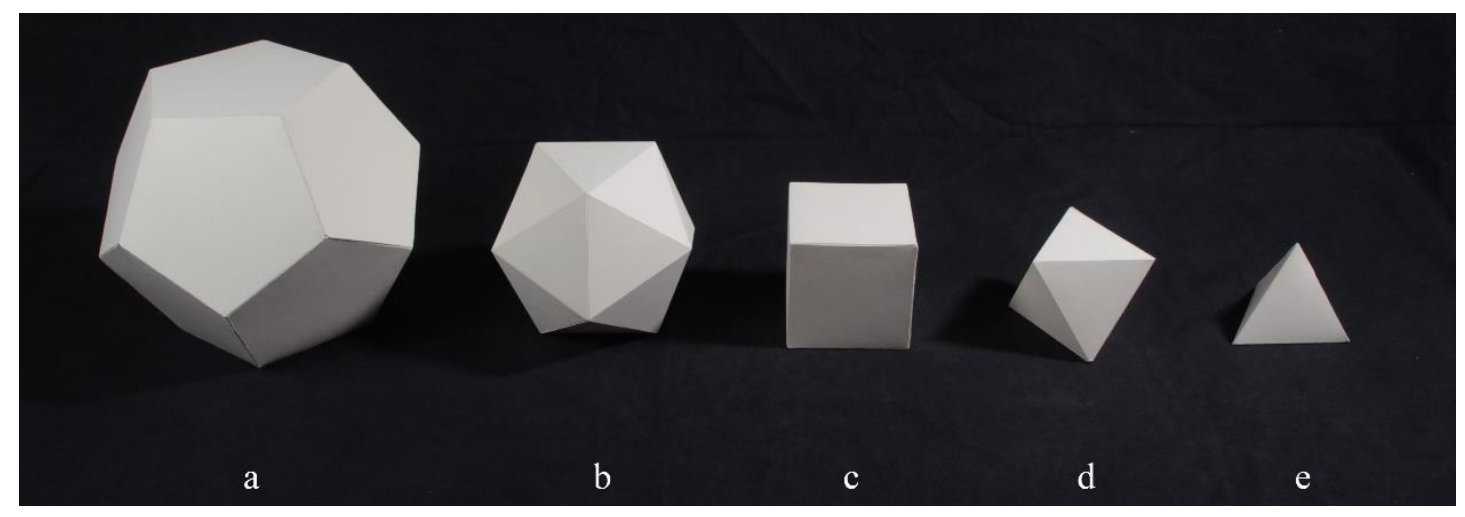

Şekil 3. a. Dodekahedron, b. İkosahedron, c. Hekzahedron, d. Oktahedron, e. Tetrahedron (Rabia Akgül Arşivi)

Pythagoras (M.Ö.580-504) ilk ilkenin sayı olduğunu, nesnelerin algılanan sayılardan oluştuğunu ve ilk varlığın nokta olduğunu ileri sürmüştür. Bu bakış açısından hareketle ilk varlık nokta, noktanın devinimi çizgiyi, çizginin devinimi yüzeyi, yüzeyin devinimi de hacmi yani cismi oluşturmaktadır. Böylece nesnenin sayısal değişimi onların niteliksel farklılıklarına karşılık olmaktadır (Hançerlioğlu, 2010:312).

Platon (M.Ö.427-347) düzgün polihedronları temel maddelere karşl1ı olarak görmektedir. Buna göre toprak küp, hava oktahedron, ateş tetrahedron ve su ikosahedron uzaysal biçimlerin kombinasyonudur (Hançerlioğlu, 2010:269).

Timaeus'da şöyle geçmektedir; Kübü yeryüzüne atalım, çünkü cisimlerin en hareketsizidir... benzer şekilde diğer figürlerin en az hareketli olanını (ikosahedron) suya, daha hareketlisini (tetrahedron) ateşe, ve en yüksek değeri (oktahedron) havaya atalım (Stevens, 1990:112).

Plato'nun kitabı Timaeus, orta çağlarda bilinen az sayıdaki Klasik Yunan metinlerinden biridir. Timaeus'da Platonun fiziksel evrenin dört elementten oluştuğundan bahsedilir. Stevens (1990), bu ayrımı maddenin, katı sıvı gaz ve plazma hallerine karşılık geldiği şeklinde değerlendirir.

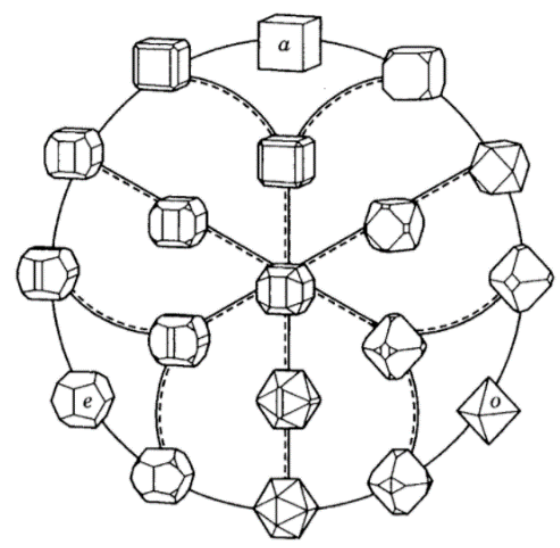

Şekil 4. Cansız Doğanın Kristal Biçim Varyasyonları (Sunagava, 2005:80) 
Pisagor, kusursuzluk, uyum ve güzelliği ima etmek için kristal kelimesini kullanır ve Platon, toprak, hava, ateş suları ve evrene ilişkin ünlü beş polihedronu sıralar (Sunagava, 2005:84). Kristal yapıların biçimlenme varyasyonlarına bakıldığında, temel polihedronlardan eksiltilmek, ya da ötelenmek suretiyle türediği ve temel polihedronların birbirlerine dönüşüm aşamalarından ibaret olduğu gözlemlenmektedir (Şekil 4).

Maddeler fiziki faklılıkları nedeniyle doğada farklı geometrik düzenler halinde bulunurlar. Katı, sıvı gaz halindeki moleküler birimlerin temelinde uzaysal örgütlenme ilkeleri bulunmaktadır. Metal ve minerallerin kristal strüktürlerine bakıldığında simetri özelliğine sahip polihedral birleşme biçimleri görülmektedir (Şekil 5).

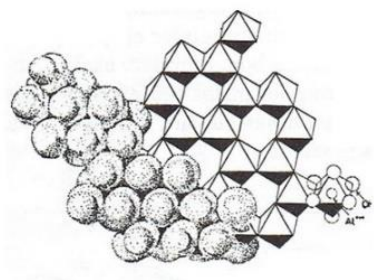

aliminyum hidroksit

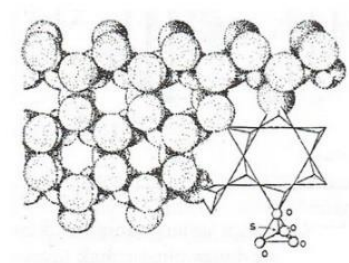

silisyum tetra oksit

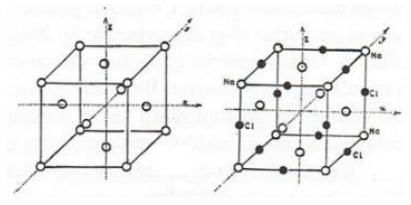

bakır kayatuzu

Şekil 5. Çeşitli Kristaller (Yurtsever, 2008:55)

Canlı organizmaların yapılarında protein, su tuz, vitamin metal, yă̆ ve karbonhidratlar bulunmaktadır. Biyolojik yapı taşları bünyelerindeki kohezyon gerilimleri nedeniyle bir arada denge oluşturmak için çeşitli şekillerde örgütlenerek tek hücreli canlılar olan virüs ve bakterileri oluştururlar... Basit canlıların strüktürlerinin daha kararlı geometrik görünümlere sahip olmalarına karşlık yetişkin canlılarda geometrik kararlılık kaybolur (Yurtsever, 2008, s.68) (Şekil 6.).
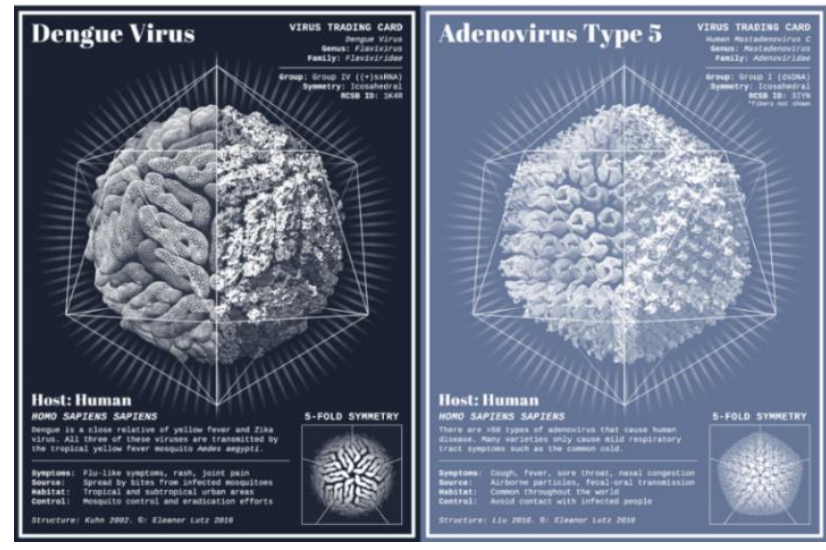

Şekil 6. Küçük Canlılardan, Virüs (URL 5) 
En küçük düzgün poligon olan eşkenar üçgenden başlayıp kare, düzgün beşgen ve daha büyük çokgenlerin bir uzay parçasını sınırlamak üzere örgütlenme olasılıklarına bakıldığında beş tür düzgün polihedron olacağına ulaşılmaktadır (Sunagawa, 2005:66). Bir tepe noktasını paylaşmak üzere ancak üçer, dörder ve beşer adet eşkenar üçgen yüzeyler kendi aralarında örgütlenerek düzgün polihedronları tanımlayabilirler (Karakırık, 2011:125). Temel polihedronlar yüzey sayılarına göre düzgün dörtyüzlü, düzgün altıyüzlü, sekizyüzlü, onikiyüzlü ve yirmiyüzlü olarak adlandırılmaktadırlar (Şekil 7). Her bir düzgün çokyüzlünün içerisine yüzey merkez noktalarına tepe noktası gelecek şekilde ikinci bir çokyüzlü yerleştirilebilir. Bu iki çokyüzlüye birbirinin "eş" çokyüzlüsü veya eşleniği denmektedir.

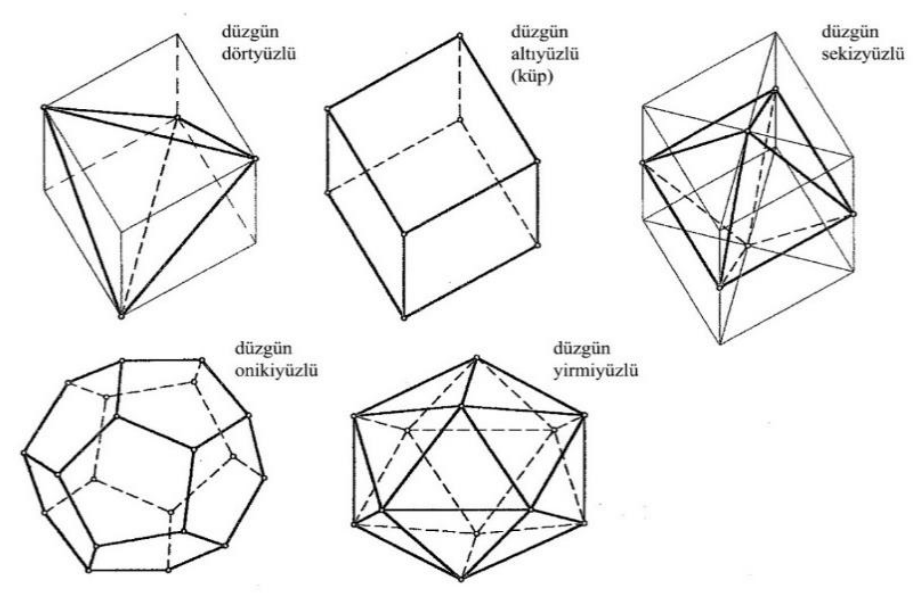

Şekil 7. Düzgün Çokyüzlüler Serisi (Rabia Akgül Arşivi)

Poligonlarda köşe ve kenarların, polihedronlar da tepe kenar ve yüzeylerin sayıları, şekilleri ve örgütlenişleri belirli geometrik yasalara bağımlıdır. Bir poligonun köşe ve kenar sayılarının birbirine eşit olmasına karşın, polihedronların tepe ve yüzey sayıları toplamı kenar sayısının iki fazlasına eşittir (Tablo 1).

Tablo 1. Poligon ve Polihedronların Köşe, Kenar, Yüzey ve Tepe Noktası Bağıntıları.

\begin{tabular}{|l|l|}
\hline POLİGON & POLİHEDRON \\
\hline K=A & T+Y=A+2 \\
\hline Tepe Sayıs1 & T \\
\hline Yüzey Sayı1 & Y \\
\hline Kenar(Ayrit) Sayıs1 & A \\
\hline Köşe Sayıs1 & K \\
\hline
\end{tabular}

Köşe açları ve kenar uzunlukları kendi aralarında eşit olmak koşulu ile sonsuz sayıda düzgün poligon (çokgen) bulunmasına karşın, tepe açıları, kenar sayısı ve uzunlukları, yüzey sayısı, şekli ve 
ölçüleri kendi aralarında eşit olmak koşulu ile ancak beş adet düzgün polihedron (çokyüzlü) bulunmaktadır (Şahinler ve Kızıl, 2014:144).

Tablo 2 den de takip edilebileceği üzere eş polihedronların kenar sayıları birbirlerine eşittir. Yüzey ve tepe sayıları arasında ise çapraz bir bağıntı söz konusudur. Her bir temel polihedronun eşleniğine baktığımız zaman, tetrahedronun eşleniğinin yine kendisi olduğu, küpün eşleniğinin oktahedron olduğunu, yirmiyüzlünün eşleniğinin de onikiyüzlü olduğunu görürüz.

Tablo 2. Temel Polihedronlar Arasındaki Köşe, Kenar Yüzey Sayıları, Eşlenikler

\begin{tabular}{|c|c|c|c|c|c|}
\hline \multirow[t]{2}{*}{ POLİHEDRON } & \multicolumn{2}{|c|}{ YÜZEY ŞEKİLLERİ } & \multirow[b]{2}{*}{$\begin{array}{l}\text { YUUZEY SAYISI } \\
\text { Eş polihedronun } \\
\text { köşe } \quad \text { sayısına } \\
\text { eşittir }\end{array}$} & \multirow{2}{*}{$\begin{array}{l}\text { KÖŞE SAYISI } \\
\text { Eş } \\
\text { polihedronun } \\
\text { yüzey sayısına } \\
\text { eşittir }\end{array}$} & \multirow{2}{*}{\begin{tabular}{ll}
\multicolumn{2}{l}{ KENAR SAYISI } \\
\multicolumn{2}{l}{ Eş polihedronların } \\
kenar & sayıları \\
essittir &
\end{tabular}} \\
\hline & $\begin{array}{l}\text { Bu } \\
\text { kolondaki } \\
\text { tüm } \\
\text { yüzeyler } \\
\text { eşkenar } \\
\text { üçgendir }\end{array}$ & $\begin{array}{l}\text { Yüzeylerin } \\
\text { kenar saylları } \\
\text { giderek artar }\end{array}$ & & & \\
\hline TETRAHEDRON & & $\triangle$ & 4 & 4 & 6 \\
\hline TETRAHEDRON & $\triangle$ & & 4 & 4 & 6 \\
\hline HEGZAHEDRON & & $\square$ & 6 & 8 & 12 \\
\hline OKTAHEDRON & $\triangle$ & & 8 & 6 & 12 \\
\hline DODEKAHEDRON & & 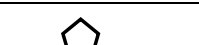 & 12 & 20 & 30 \\
\hline IKOSAHEDRON & $\bigwedge$ & & 20 & 12 & 30 \\
\hline \multirow[t]{2}{*}{ DÜZLEM } & & $\square$ & & & \\
\hline & $\triangle$ & & & & \\
\hline
\end{tabular}

Tüm biçimlerin temel polihedronlardan eksiltip çıkartılarak elde edildiği savı, temelde biçimlendirme işlevi yapan her mimar için şüphesiz dikkat çekicidir. Fuller, Le Corbusier, Da Vinci gibi isimlerin bu konuda incelemeler yapmış olması da dikkat çekmektedir. Mimarlık bağlamında baktığımızda ise misır piramitlerinden günümüze kadar kararlı yalın geometrisiyle mekân biçimlenmesinde kullanıldığı göze çarpmaktadır (Şekil 8). Uluslararası platformda gerek mimarlık eğitimde, gerek yapılı çevrede polihedron tabanlı strüktürlerin kullanıldığı gözlenmektedir.
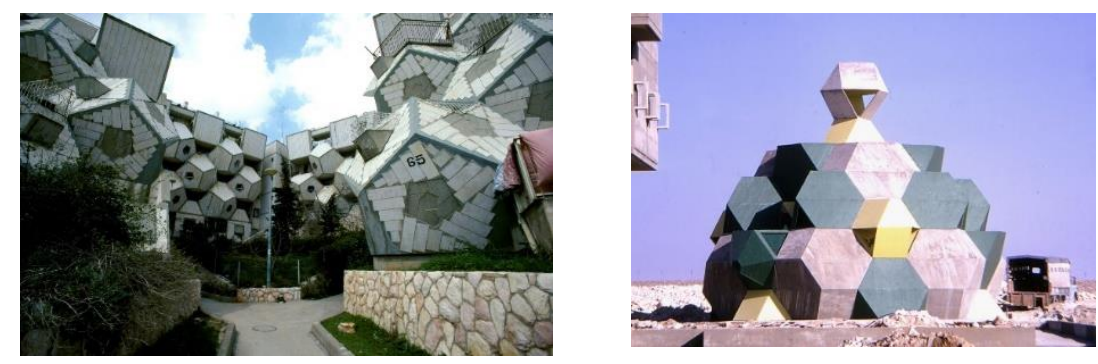

Şekil 8 a. Ramot Toplu Konut Projesi ${ }^{4}$ b. Negev Çölü Sinagogu (URL 6) 


\section{POLİHEDRONLARIN ÜÇ BOYUTLU BİÇİMLENDİRMEYE ETKILLERİ ÜZERİNE DENEYSEL BİR ÇALIŞMA (AN EXPERIMENTAL STUDY ON THE EFFECTS OF POLYHEDRONS ON THREE DIMENSIONAL FORMING)}

Temel tasarım amaç ve ilkeleri kapsamında ve polihedronların geometrisi 1şı̆̆ında deneysel bir temel tasarım atölyesi kurgulanmıştır. Bu deneysel çalışmasının amacı; mimarlık temel tasarım eğitiminde iki boyuttan üç boyuta geçişteki temel geometrik ilkelerin kavranmasına yönelik bir yöntem geliştirmektir. Karmaşık bir üç boyutlu tasarım ortamında biçim organizasyonları ile mekân tasarımının temel ilkelerini ortaya koymak amaçlanmaktadır. Deneysel çalışma temel tasarım dersini almış birinci sınıf öğrencileri üzerinde gerçekleştirilmiştir.

Çalışmanın yöntemi; Armstrong’un bir zeka kullanımından diğerine geçiş için önerdiği tanımlama, deneyimleme, sorgulama aşamaları esasında kurgulanmıştır (Armstrong, 2009:68) (Tablo 3). Bu kurgu içinde:

Tanımlama aşamasında; yapılan literatür taraması, çizim ve maket üretimleri eşliğinde temel polihedronlar hakkında kavramsal bilgi verilmiş ve çalışmanın amacı kapsamı ve yöntemi tanımlanmıştır. Bu bağlamda öncelikle temel polihedronların tarihi ve kullanım alanlarına ilişkin bilgiler verilmiştir. Daha sonra temel polihedronların geometrik yapılarına odaklanılıp, ortogonal koordinatlardaki çizimleri incelenmiştir. Temel polihedronların geometrisinin, düzgün çokgenlerin üçüncü boyutta kenar ve köşe noktalarından birleşerek oluştuğunun bilgisi verilmiştir. Her bir polihedron kapalı yüzeyler, açık yüzeyler ve küresel birimlerden oluşacak şekilde yapılan üç boyutlu maketleriyle tanıtılmıştır. Maket üzerinden tanıtımı yapılırken her bir polihedronun tepe noktası, ayrıt ve yüzeyden bakış olmak üzere üç tür görünüşüne odaklanılmıştır.

Tablo 3. Deneysel Çalışma Süreci

\begin{tabular}{|l|l|}
\hline TANIMLAMA & $\begin{array}{l}\text { Polihedronların tanıtılması ve çalışma yöntem ve } \\
\text { hedeflerinin belirlenmesi. }\end{array}$ \\
\hline \multirow{2}{*}{ DENEYIMLEME } & $\begin{array}{l}\text { Polihedronların çizimleri. } \\
\text { Polihedronların modellerinin hazırlanması } \\
\text { Polihedronların paketlenmesi, }\end{array}$ \\
\hline \multirow{2}{*}{ SORGULAMA } & $\begin{array}{l}\text { Anket uygulaması } \\
\text { Sonuç ve Değerlendirme }\end{array}$ \\
\hline
\end{tabular}

Deneyimleme aşamasında; öğrencilerin çizim ve maket yöntemlerini kullanarak edindikleri kavramsal bilgiyi önce içselleştirmesi sonra da öğrencilerin gruplara ayrılarak temel polihedron kullanımı ile hacimsel tasarımlar gerçekleştirmesi beklenmiştir. Deneyimleme aşaması, kendi içerisinde üç bölümden oluşmaktadır. Bunlar; Polihedronların çizimleri, modellerinin hazırlanması ve üç boyutlu uzayda modüler paketlenmeleridir. İlk bölümde, öğrencilerin adım adım polihedral biçimleri nasıl görecekleri ve matematiğini kurarak algoritmik olarak nasıl çizebilecekleri anlatılmıştır. Öğrencilerden kendi içerisinde tutarlı mantıklar kurarak polihedronların çizimlerini yapmaları beklenmiştir. Yapılan çizimlerin üzerinden farklı çizim yöntemleri tartışllmıştır. Polihedronların çizimleri sırasında kullanılan altın oran ayrı bir tartışma konusu olmuş ve bilgisi 
verilmiştir. İkinci bölümde, Polihedronların modellerinin yapım yöntemine karar verirken elde edilecek üç boyutlu biçimin, iki boyutlu biçimlerle ilişkisinin de kavranabilmesi için, katlama (folding) ve strüktürel paketlenme (structural packaging) yöntemi seçilmiştir. Böylece eşkenar çokgen yüzeylerin bir tepe noktasında birleşme sayıları, açıları ve dayanıklı bir katı ifade için birleşme biçimlerinin kavranması hedeflenmiştir. Üçüncü bölümde, öğrenciler bireysel olarak, polihedronların modüllerini oluşturmuşlardır. Oluşturulan modüller bir araya getirilerek her bir polihedron için ayrı bir çalışma grubu oluşturulmuştur. Çalışma gruplarından her biri kendi polihedral biçimiyle ne yapabileceğini kurgularken, kendilerine verilen tasarım alanında bir yer seçmişlerdir. Seçtikleri yer bağlamlarını oluşturmuştur. Kolon yüzeyi, dolaşım alanı, oturma birimi, sergi birimi gibi bağlamlarda çalışan öğrenciler, yere özgü sistemler kurmuşlardır (Şekil 9).

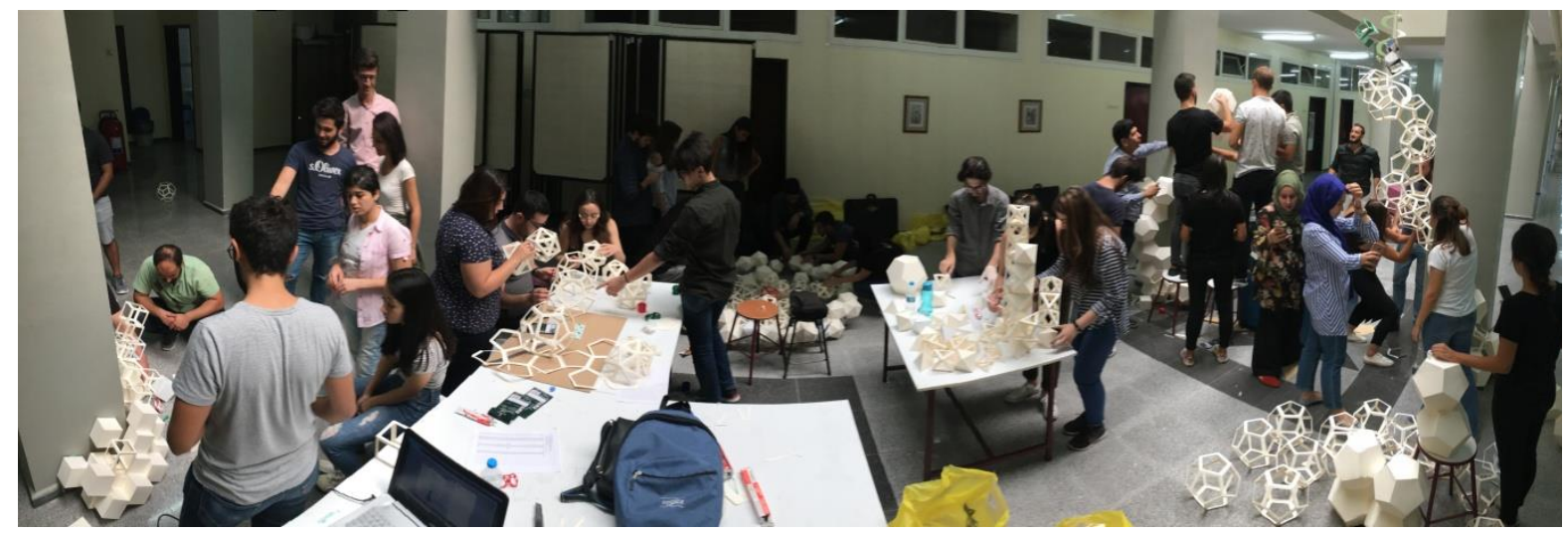

Şekil 9. Deneyimleme Aşaması Öğrenci Çalışmaları (Rabia Akgül Arşivi)

Tetrahedron modellerle çalışan öğrencilerin masa üzerinde potansiyel birleşim biçimlerini denedikleri ve sonuç ürünlerini zemine oturur biçimde tasarlayıp sergiledikleri gözlemlenmiştir (Şekil 10). Oluşturulan örüntüde tetrahedronlar kenar ve yüzeylerinden birleşecek şekilde organize edilmişlerdir. Tetrahedronlarla oluşturulan örüntü bir tarafta karmaşı boşluklu bir yapıda yoğunlaşırken, diğer tarafta hacimsel bir kol atarak yere temas etmektedir. Bu modülle çalışan öğrencilerin oluşturdukları biçimi zemininde kamusallık bulunan bir mega strüktür olarak tanımlamaları dikkat çekmiştir. Bu tanıma bakıldığında yap1 zemine minimum temas eden, tetrahedral yapısıyla dev bir uzay kafes sistemi bünyesinde barındırmaktadır.

Küp ile çalışan öğrenci grubu çevrede gördükleri hemen her yapının üst üste yığılmış küpler gibi olduğunu ifade ederek küpün kendisi ile uzayda boşluksuz paketlendiğinin farkındalığını dile getirdikleri görülmüştür. 

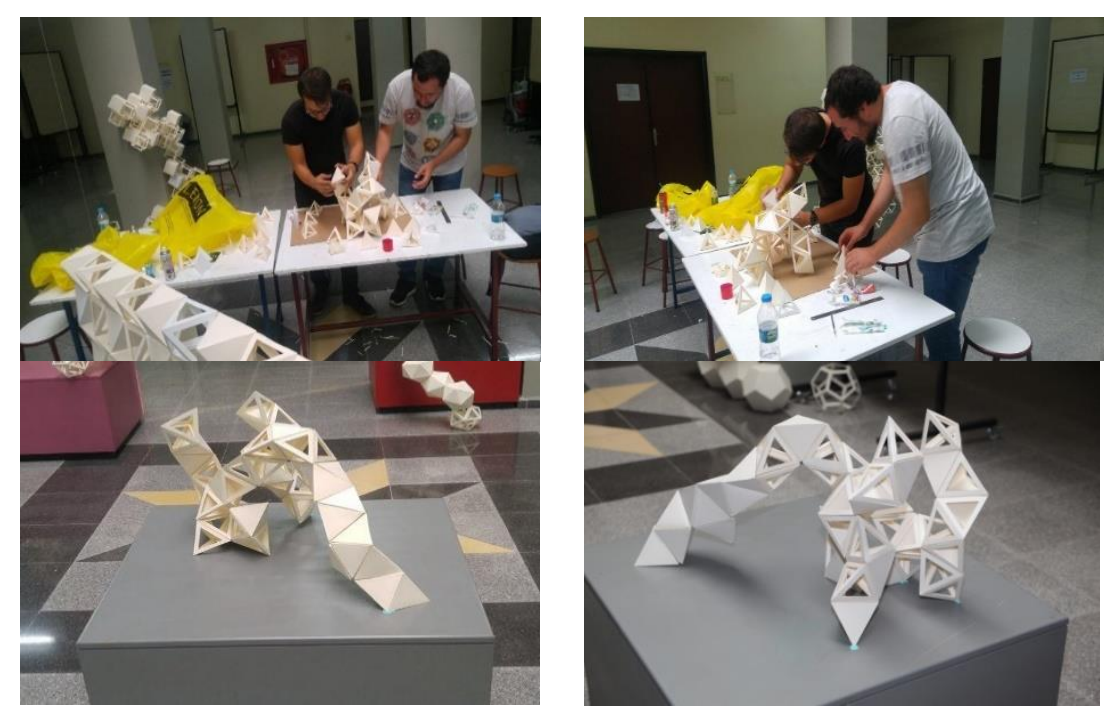

Şekil 10. Tetrahedron Modüllerle Oluşturulan Örüntü Çalışmaları (Rabia Akgül Arşivi)

"Küp ile farklı ne yaparız" a bakıldığında bir bağlam, bir düşey kolon yüzeyine eklemlenerek tırmanan bir paketlenme biçimi öğrenciler tarafindan tercih edilmiştir. Birbirine eş ölçüde olan küp modüllerin yüzeyleri tamamen birbirini örtmeyecek şekilde kaydırılarak örüntü oluşturulmuştur. Yükseldikçe kolon yüzeyine tutunarak ayakta duran bu örüntüde, üst kısımlara geldikçe boş yüzeyli küpler kullanılarak taşıyıcı sistemin hafifletildiği gözlemlenmiştir (Şekil 11).
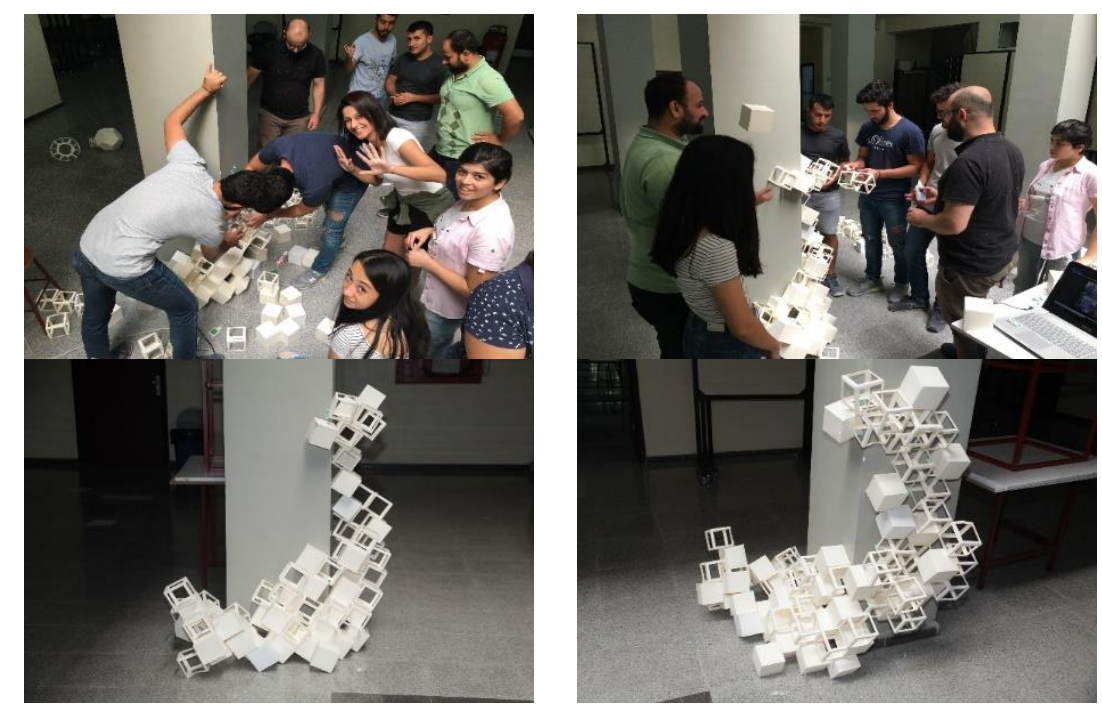

Şekil 11. Hekzahedron Modüllerle Oluşturulan Örüntü (Rabia Akgül Arşivi)

Oktahedron modüllerle çalışan öğrencilerin her bir modülü, bir diğerinin ayrıtıyla eşleyerek birleştirdikleri görülmüştür. Dolu ve boş oktahedron modüllerin bir arada kullanıldığ1 sonuç ürünün 
bir yüzey dokusu tanımladığ1 gözlenmiştir. Doku içerisinde dolu yüzeyli ve boş yüzeyli oktahedronların sıralı düşey sütunlar halinde kullanıldığı, ara ara modül boşaltması yapılarak simetrinin bozulduğu görülmüştür. Boşaltmaya rağmen göz örüntünün kendi içerisindeki bu düzeni takip edebilmektedir. Herhangi bir yan yüzeye dayanmayan bu bağımsız örüntünün boşluklu bir duvar yüzeyine dönüştügü görülmüștür (Şekil 12).
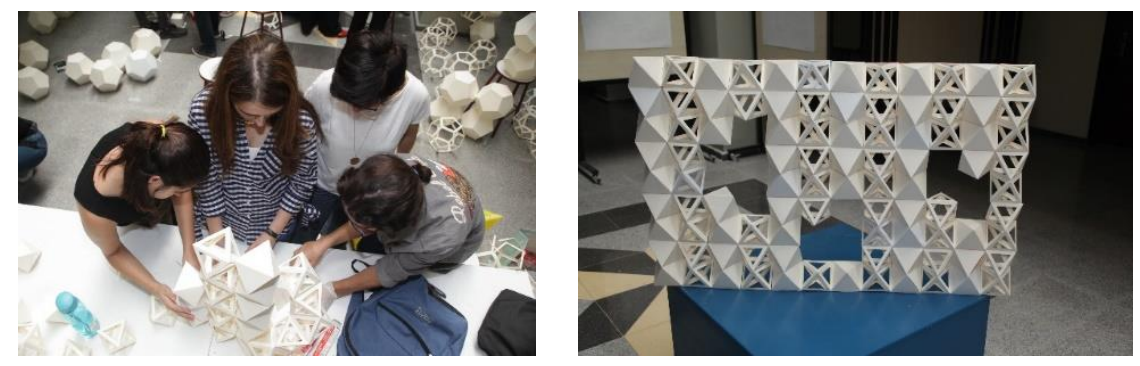

Şekil 12. Oktahedron Modüllerle Oluşturulan Örüntü (Rabia Akgül Arşivi)

Dodekahedron modüllerle çalışan öğrenciler kendi aralarında iki gruba ayrılmışır. Her iki grupta zeminden başlayıp ortada birleşecek ve altından bir insanın geçebileceği bir kemer oluşturmuştur (Şekil 13). Yapım sırasında dolu ve boş yüzeyli modüllere eşit davranmalarından dolayı üst kısımlara geldikçe malzemenin taşınmasına ilişkin problemlerin ortaya çıktığı görülmüştür.
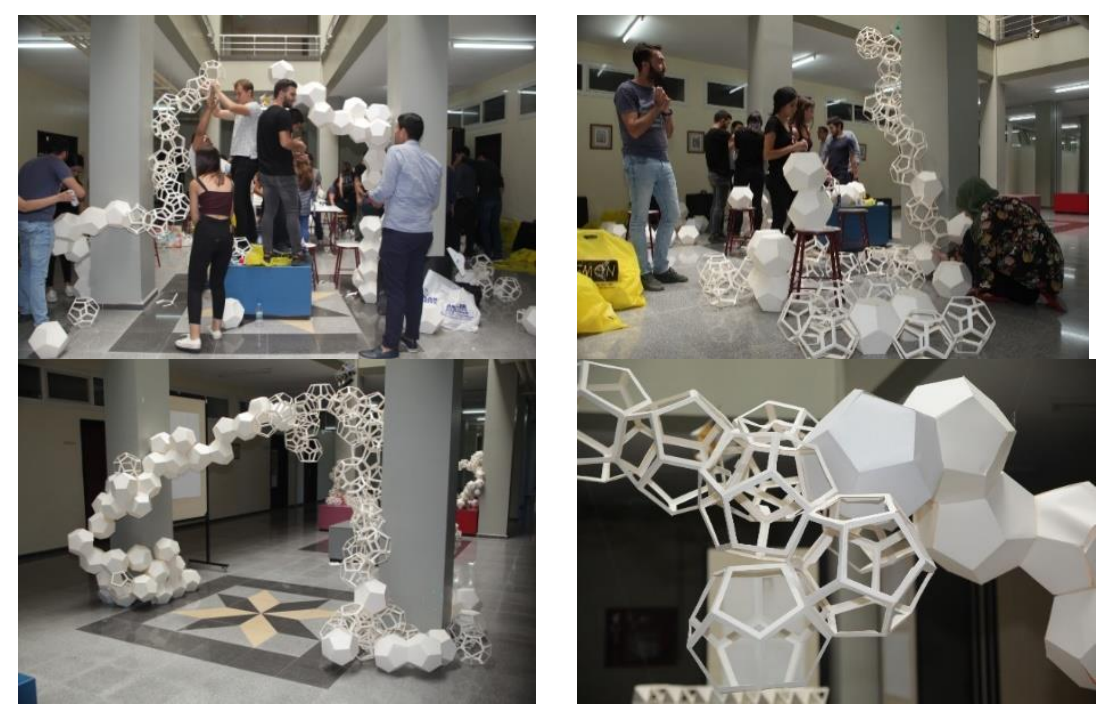

Şekil 13.. Dodekahedron Modüllerle Oluşturulan Örüntü (Rabia Akgül Arşivi)

İnsan ölçeğinin dikkate alındığ1 ikosahedron grubunda, oturan bir öğrencinin çevresinde oluşturulan modüllerle üst örtü oluşturulmaya çalışıldığ1 görülmüştür (Şekil 14). "Yer" e tutunma arayışları ikosahedron ile çalışan grubun deneyim çerçevesini oluşturmuştur. Temel polihedronların 
paketlenmesiyle tasarım oluşturma deneyiminde ikosahedron modüller öğrencilerin en fazla zorlandığı tasarım nesnesi olmuştur.
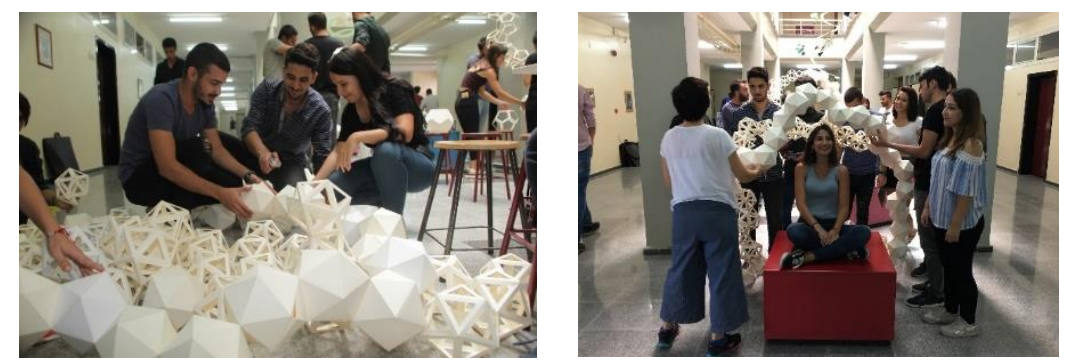

Şekil 14. İkosahedron Modüllerle Oluşturulan Örüntü (Rabia Akgül Arşivi)

Sorgulama aşamasında öğrencilere anket uygulanarak kazanımlarına ilişkin değerlendirmeye yönelik veri toplanmış ve bu veriler istatistiksel veri analiz programı ile incelenerek yorumlanmıştır. Tanımlama ve deneyimleme aşamalarından geçen öğrencilerin deneysel çalışma sürecini geriye dönük tekrar değerlendirmesini sağlayan ters yönlü bir süreç olduğu düşünülebilir. Sorgulama öğrencinin çalışması sürecinde hangi aşamada, hangi kazanımları edindiğini fark edebileceği kisımdir.

$\mathrm{Bu}$ aşamada öğrencilerin bilgileri ve kazanımlarının ölçülmesi ve elde edilecek bilgilerle, temel tasarım eğitiminde üç boyutlu biçim algısını geliştirmeye yönelik uygulanan bu yöntemin değerlendirmesini yapabilmek amaçlanmıştır.

Anket soruları kurgulanırken öncelikle sorgulanacak konular belirlenmiştir. Uygulanan anket, sorguladığı konu bakımından kendi içerisinde "bilgi ölçen", "bilgiyi bütünleştiren" ve "kazanımları belirleyen" olmak üzere üç gruba ayrılmakta ve toplamda on dört sorudan oluşmaktadır. Her bir konu içerisindeki sorular hazırlanırken ise, bilginin zihinden çağrılma biçimini etkilediği düşünülen soru stili farkl111klarına gidilmiştir:

- Öğrencilerin hedefe kilitlenen, ezberci zihinden çıkarmak amacıyla birbirinden farklı, birden fazla doğrunun olabildiği, çok seçenekli sorular hazırlanmıştır.

- Bireysel, grup ve tasarım nesnesine ilişkin kazanımların ölçüldüğü sorularda beklenen kazanımlar listelenmiş ve öğrencilerin bireysel seçimlerini analiz etmek hedeflenmiştir.

Anket çalışması ile elde edilen veriler istatistik değerlendirme programına (SPSS) aktarılarak cevapların frekans değerleri incelenmiştir. Çalışmanın beklentilerine göre çapraz karşılaştırmalar yapılmış, değişkenler arasındaki ilişkiler ortaya konmuştur. 


\section{BULGULAR (FINDINGS)}

Mimarlık temel tasarım eğitiminde öğrencilerin üç boyutlu biçim algısını geliştirecek ve hesaplamalı tasarıma geçişe altlık oluşturabilecek bir biçimlendirme yöntemi için araç olarak seçilen temel polihedronlar ile yapılan deneysel çalışma sonucunda aşağıdaki bulgular tespit edilmiştir:

\section{Bilgi Ölçen Soruların Değerlendirilmesi}

Anket uygulamasında öğrencilerin "Hangisi uzaysal kapalı bölgelere verilen isimdir?” sorusuna verdiği cevaplar incelendiğinde, \%71,4’ünün polihedron (çokyüzlü) doğru cevabını verdiği tespit edilmiştir (Grafik 1).

\begin{tabular}{|l|l|l|}
\hline Seçenekler & Frekans & Yüzde (\%) \\
\hline Poligon & 8 & 19 \\
\hline Polihedron & 30 & 71,4 \\
\hline Yüzey & 4 & 9,5 \\
\hline Toplam & 47 & 100 \\
\hline
\end{tabular}

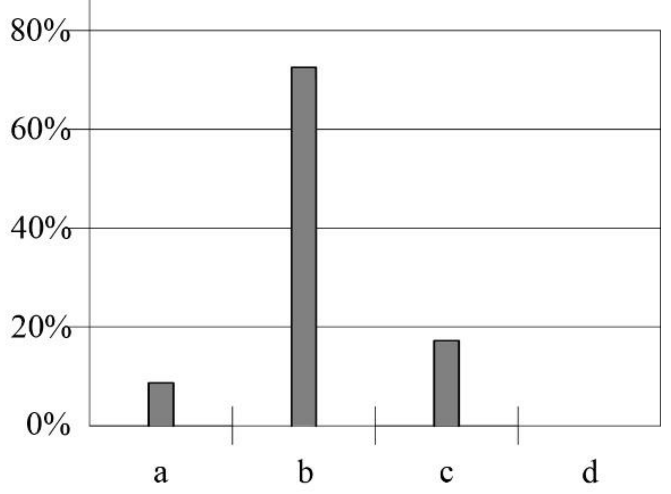

Grafik 1. Uzaysal Kapalı Bölgeler

"Hangisi yüzeysel kapalı bölgelere verilen isimdir?” sorusuna verilen cevaplar incelendiğinde \%66,7'sinin poligon(çokgen), \%28,6'sının polihedron (çokyüzlü) cevabını verdiği tespit edilmiştir. Doğru cevap poligondur ve öğrencilerin \%66,7’si bu soruya doğru cevap vermiştir (Grafik 2).

\begin{tabular}{|l|l|l|}
\hline Seçenekler & Frekans & Yüzde (\%) \\
\hline Poligon & 28 & 66,7 \\
\hline Polihedron & 12 & 28,6 \\
\hline Yüzey & 1 & 2,4 \\
\hline Tepe noktas1 & 1 & 2,4 \\
\hline Toplam & 42 & 100 \\
\hline
\end{tabular}

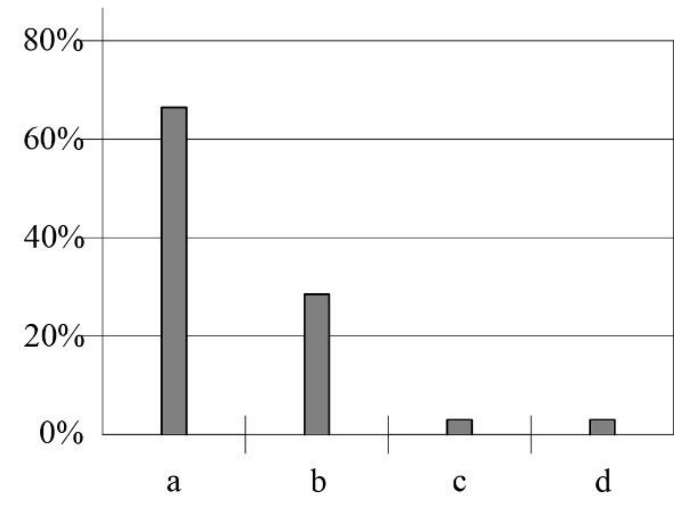

Grafik 2.Yüzeysel Kapalı Bölgeler 
Uzaysal kapalı bölge ve yüzeysel kapalı bölge kavramlanna karşılık gelen poligon ve polihedron kavramlarının sorgulandığı soruların doğru yanıtlanma yüzdelerine bakıldığında büyük ölçüde kavramların öğrencinin zihninde yerleștiği sonucuna varılabilir.

Öğrencilerin "En büyük ve en küçük çokgenler hangi seçenekte birlikte verilmiştir?” sorusuna verdiği cevaplar incelendiğinde \%59,5’inin daire-üçgen, \%33,3’ünün ise tetrahedron-dodekahedron cevabını verdiği tespit edilmiştir. Doğru cevap daire-üçgen seçeneğidir ve öğrencilerin \%59,5’i bu soruya doğru cevap vermiştir (Grafik 3).

\begin{tabular}{|l|l|l|}
\hline Seçenekler & Frekans & Yüzde (\%) \\
\hline Daire-Üçgen & 25 & 59,5 \\
\hline Üçgen-Beşgen & 3 & 7,1 \\
\hline $\begin{array}{l}\text { tetrahedron- } \\
\text { dodekahedron }\end{array}$ & 14 & 33,3 \\
\hline Toplam & 42 & 100 \\
\hline
\end{tabular}

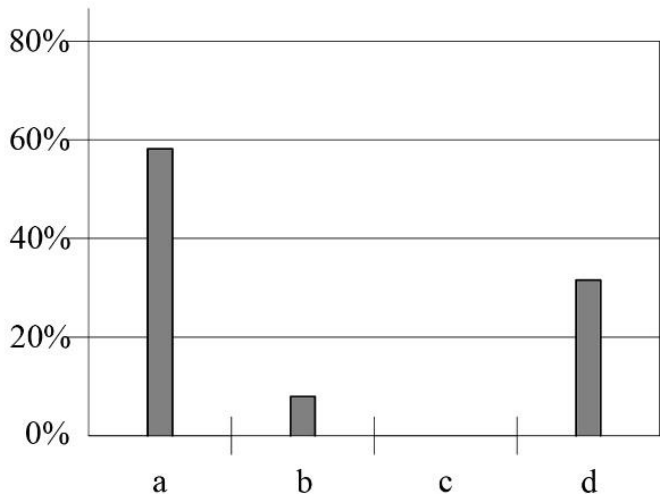

Grafik 3.En Büyük ve En Küçük Çokgenler

"Hangisi şekildeki polihedronların arasındaki ilişkiyi ifade etmez?" sorusuna verilen cevaplar incelendiğinde; eşlenik kavramının ve birbirinin eşleniği olan biçimlerin arasındaki ilişkinin sınandığ1 bu soruda öğrencilerin \%64,3’ü doğru cevap vermiştir (Grafik 4).

\begin{tabular}{|l|l|l|}
\hline Seçenekler & Frekans & Yüzde (\%) \\
\hline Birbirlerinin Eşleniğidirler & 1 & 2,4 \\
\hline $\begin{array}{l}\text { Birinin tepe sayısı diğerinin } \\
\text { yüzey sayısına eşittir }\end{array}$ & 7 & 16,7 \\
\hline $\begin{array}{l}\text { Kenar sayıları } \\
\text { birbirine eşittir }\end{array}$ & 7 & 16,7 \\
\hline Yüzey şekilleri eştir & 27 & 64,3 \\
\hline Toplam & 42 & 100 \\
\hline
\end{tabular}

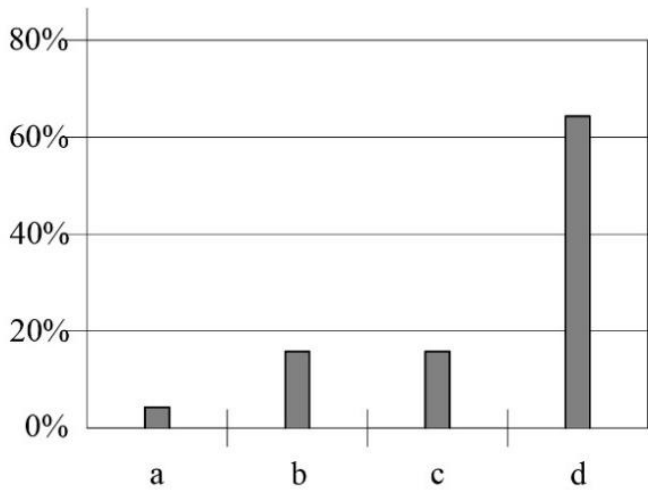

Grafik 4. Polihedronların Arasındaki İlişki 
Tüm polihedronların bir arada tepe kenar yüzey sayıları ve görünüşleri ile birlikte verildiği beşinci soruda amaç, öğrencinin tüm bilgiyi bir arada görerek çıkarım yapabilmesidir. "Tabloya göre temel polihedronlara ilişkin aşağıdakilerden hangileri doğrudur?” sorusunda a,b,c,d seçenekleri doğru seçenekler olup, öğrencilerin \%37,7 ile \%11,7 arasında değişen oranlarda doğru cevap verdikleri tespit edilmiştir. Öğrencilerin oldukça düşük bir oranda, \%5,2'sinin yanlış cevap olan eşkenar üçgen yüzeyli çokyüzlülerin kenar sayıları eşittir cevabını verdiği tespit edilmiştir. Tüm doğru seçenekleri aynı anda işaretleyebilen öğrenci yüzdesi 11,7 dir. Çoklu yanıt olduğu için N sayısı örneklem hacmini geçmektedir (Grafik 5).

\begin{tabular}{|l|l|l|}
\hline \multirow{2}{*}{ Seçenekler } & \multicolumn{2}{|c|}{ Yanıtlar } \\
\cline { 2 - 3 } & Frekans & Yüzde (\%) \\
\hline $\begin{array}{l}\text { Bir düzgün çokyüzlünün tepe, kenar } \\
\text { ve yüzeyleri arasındaki bağıntı; } \\
\text { Yüzey sayısı + Tepe Sayısı =Kenar } \\
\text { sayısı + 2'dir. }\end{array}$ & 29 & 37,7 \\
\hline $\begin{array}{l}\text { Düzgün dörtyüzlünün cşleniği } \\
\text { yine kendisidir. }\end{array}$ & 16 & 20,8 \\
\hline $\begin{array}{l}\text { On ikiyüzlü ile yirmi yüzlü } \\
\text { birbirinin eşleniğidir. }\end{array}$ & 9 & 11,7 \\
\hline $\begin{array}{l}\text { Birbirinin eşleniği olan } \\
\text { çokyüzlülerin kenar sayılları eșittir. }\end{array}$ & 19 & 24,7 \\
\hline $\begin{array}{l}\text { Eşkenar üçgcn yüzcyli } \\
\text { çokyüzlülerin kenar sayıları eşittir }\end{array}$ & 4 & 5,2 \\
\hline Toplam & 77 & 100 \\
\hline
\end{tabular}

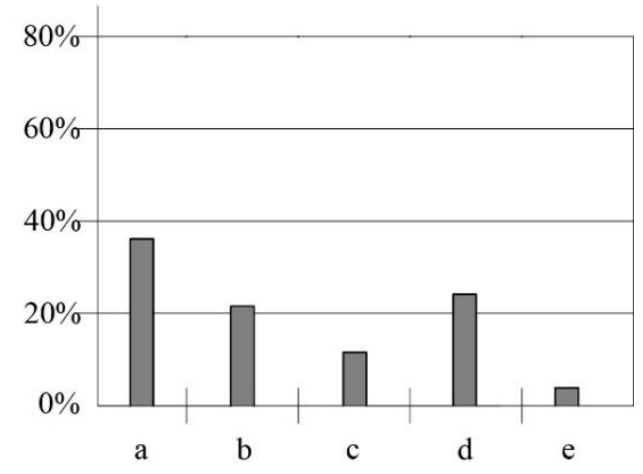

Grafik 5. Temel Polihedronlara İlişkin Hangileri Doğrudur?

Ankete katılan öğrencilerin "Verilen çokyüzlü bir tepe noktasında kaç yüzey birleşmektedir?" sorusuna verdiği cevaplar incelendiğinde $\% 7,3$ 'ünün $8, \% 7,3$ 'ünün 4, \%85,4’ünün 5 cevabını verdiği tespit edilmiştir. Doğru cevap 5 seçeneğidir ve öğrencilerin \%85,4’ü bu soruya doğru cevap vermiştir (Grafik 6).

Polihedronların kapalı bir uzay parçasını çevreleyebilmesi için yüzeylerinin bir tepe noktası oluşturacak şekilde, düzlemsel olmayan bir biçimde birleşmesi gerekmektedir. Yedinci soruda bir düzlem tanımlayan üç altıgen yüzeyin birleşimi görsel olarak verilmiş ve bu temel bilgiye dayanarak çıkarım yapmaları beklenmiştir. \% 50 oranında yanlış cevaplanan bu soruda, öğrencilerin büyük çoğunluğu, futbol topunun yüzeyinin altıgenlerden oluştuğunu belirten şıkkı işaretlemişlerdir. Futbol topunun küresel yüzeyini oluşturmada çoğunlukla tercih edilen "Truncated Icosahedron"un beşgen ve altıgen yüzeylerden bir araya geldiği bilinmektedir (Şekil 15). Bu polihedron soruda verilen şekilde bir birleşimi içermemekte, bir tepe noktasında iki altıgen ve bir beşgen yüzeyin birleşmesi ile oluşmaktadır. 


\begin{tabular}{|l|l|l|l|}
\hline Seçenekler & Frekans & $\begin{array}{l}\text { Yüzde } \\
(\%)\end{array}$ & $\begin{array}{l}\text { Geçerli } \\
\text { Yüzde(\%) }\end{array}$ \\
\hline 8 & 3 & 7,1 & 7,3 \\
\hline 4 & 3 & 7,1 & 7,3 \\
\hline 5 & 35 & 83,3 & 85,4 \\
\hline Toplam & 41 & 97,6 & 100 \\
\hline Kayıp & 1 & 2,4 & \\
\hline Toplam & 42 & 100 & \multicolumn{2}{|l}{} \\
\hline
\end{tabular}

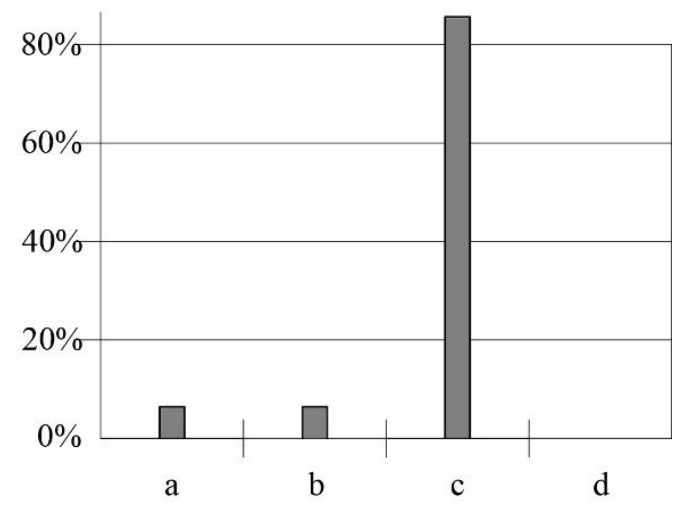

Grafik 6. Çokyüzlü Bir Tepe Noktasında Kaç Yüzey Birleşir?

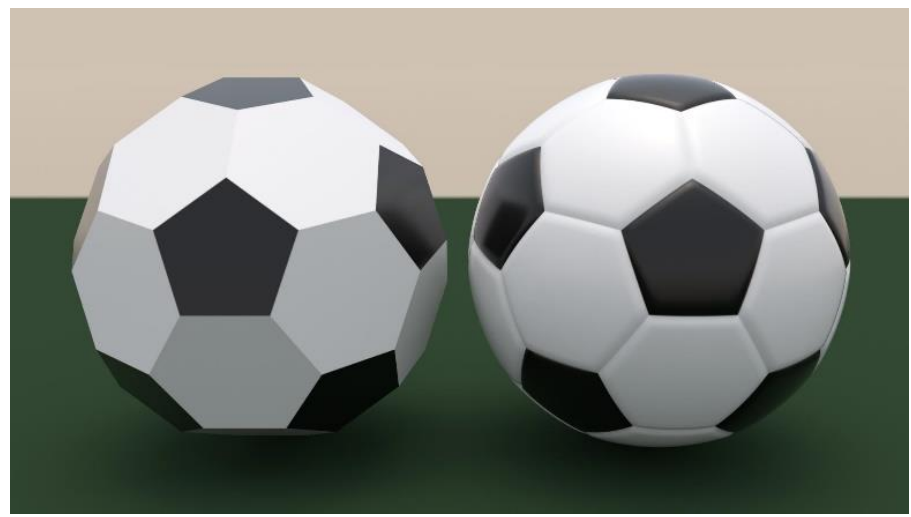

Şekil 15. Truncated İkosahedron, Futbol Topu Biçimlenmesi (Mathematica, 2017)

Öğrencilerin "Üç altıgen yüzey şekildeki gibi bir araya geldiğinde düzlem oluşturur, tepe noktas1 oluşmaz. Bu bilgiye göre aşağıdakilerden hangileri doğrudur?” sorusuna verdiği cevaplar incelendiğinde: \%29,9 ile \%17,9 arasında değişen oranlarda doğru cevap verdikleri tespit edilmiştir. Çoklu yanıt olduğu için N sayısı örneklem hacmini geçmektedir (Grafik 7). 


\begin{tabular}{|l|l|l|}
\hline \multirow{2}{*}{ Seçenekler } & \multicolumn{2}{|c|}{ Yanıtlar } \\
\cline { 2 - 3 } & Frekans & Yüzde (\%) \\
\hline $\begin{array}{l}\text { Düzgün çokyüzlü oluşturan, en fazla } \\
\text { kenar sayısına sahip düzgün çokgen; } \\
\text { beşgendir. }\end{array}$ & 16 & 23,9 \\
\hline $\begin{array}{l}\text { Futbol topunun yüzeyi } \\
\text { altıgenlerden oluşur. }\end{array}$ & 19 & 28,4 \\
\hline $\begin{array}{l}\text { Düzgün altıgen veya daha çok } \\
\text { kenara sahip düzgün poligonlar } \\
\text { kendileriyle örgütlenerek bir uzay } \\
\text { parçasını sınırlayamazlar. }\end{array}$ & 20 & 29,9 \\
\hline $\begin{array}{l}\text { Köşelerinin aynı noktayı } \\
\text { paylaşmaları durumunda sınırlı bir } \\
\text { uzay parçasııı tanımlamaları söz } \\
\text { konusu değildir. }\end{array}$ & 12 & 17,9 \\
\hline Toplam & 67 & 100 \\
\hline
\end{tabular}

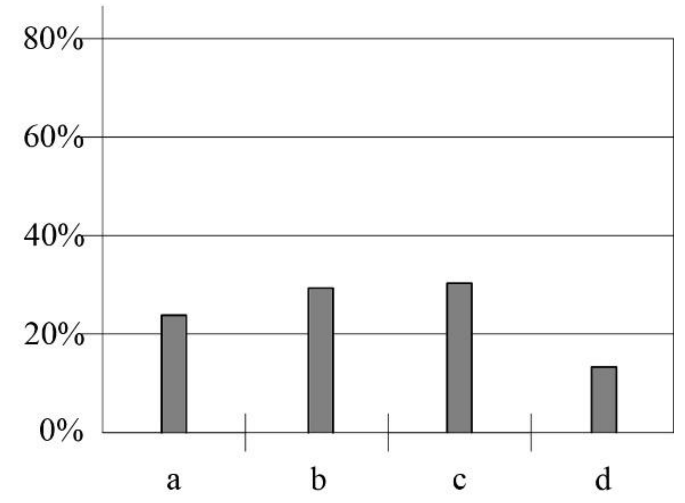

Grafik 7. Üç Altıgen Yüzeyin Düzlem Oluşturur Tepe Noktası Oluşmaz

Sekizinci soruda alan çalışmasının deneyimleme aşamasının son kısmında yapılan uzaysal örgütlenme biçimlerine ilişkin bir soru yöneltilmiştir. Ankete katılan öğrencilerin "Yüzeylerinden birleştiğinde uzayda kendisiyle boşluksuz paketlenen çokyüzlü hangisidir?" sorusuna verdiği cevaplar incelendiğinde öğrencilerin \%61,9’unun bu soruya doğru cevap verdikleri tespit edilmiştir (Grafik 8).

\begin{tabular}{|l|l|l|}
\hline Seçenekler & Frekans & $\begin{array}{l}\text { Yüzde } \\
(\%)\end{array}$ \\
\hline Tetrahedron & 7 & 16,7 \\
\hline Hekzahedron & 26 & 61,9 \\
\hline Oktahedron & 5 & 11,9 \\
\hline İkosahedron & 4 & 9,5 \\
\hline Toplam & 42 & 100 \\
\hline
\end{tabular}

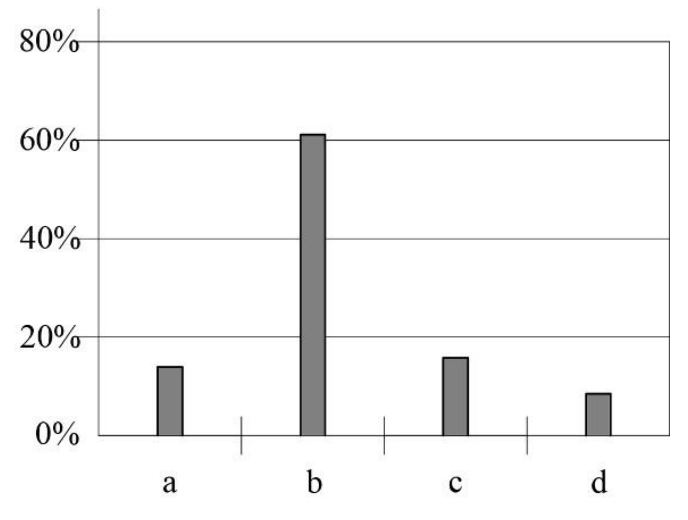

Grafik 8. Yüzeylerinden Birleştiğinde Uzayda Kendisiyle Boşluksuz Paketlenen Çokyüzlü

Dokuzuncu soruda polihedronların küresel bir yüzey oluşturacak şekilde şişirilmiş hallerini içeren görseller verilmiştir. Bu soruya ilişkin bilgiye, alan çalışmasının tanımlama kısmında değinilmemiştir. Sorunun \%74 oranında doğru cevaplanması, alan araştırmasında edinilen bilgilerin büyük oranda içselleştirilip farklı yaklaşımlarda da kullanıldığını göstermektedir. 
Ankete katılan öğrencilerin "Hangisi yirmi yüzlünün şişirilmiş halidir?” sorusuna verdiği cevaplar incelendiğinde \%74,2’sinin bu soruya doğru cevap verdikleri tespit edilmiştir (Grafik 9).

\begin{tabular}{|l|l|l|l|}
\hline Seçenekler & Frekans & $\begin{array}{l}\text { Yüzde } \\
(\%)\end{array}$ & $\begin{array}{l}\text { Geçerli } \\
\text { Yüzde(\%) }\end{array}$ \\
\hline b & 2 & 4,8 & 6,5 \\
\hline c & 23 & 54,8 & 74,2 \\
\hline d & 2 & 4,8 & 6,5 \\
\hline e & 4 & 9,5 & 12,9 \\
\hline Toplam & 31 & 73,8 & 100 \\
\hline Kayıp & 11 & 26,2 & \\
\hline Toplam & 42 & 100 & \\
\hline
\end{tabular}

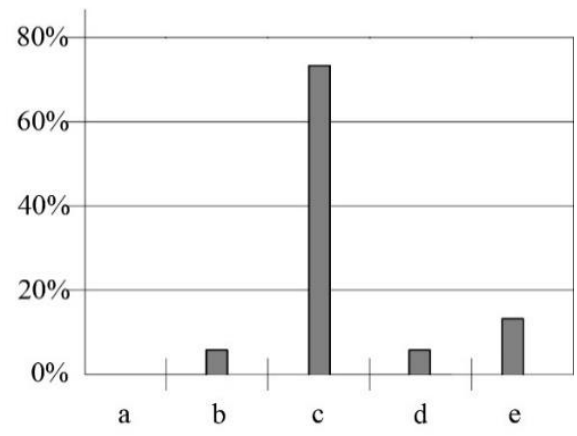

Grafik 9. Yirmi Yüzlünün Şişirilmiş Hali

On birinci soruda temel polihedronların yapılarının mükemmel simetriye sahip olması ve çizimleri sırasında kullanılan simetri eksenlerinin bilgisi ölçülmektedir. Ankete katılan öğrencilerin "Hangi çizimin simetri ekseni sayısı diğerlerinden farklıdır?” sorusuna verdiği cevaplar incelendiğinde \%65'inin bu soruya doğru cevap verdikleri tespit edilmiştir (Grafik 10).

\begin{tabular}{|l|l|l|l|}
\hline Seçenekler & Frekans & $\begin{array}{l}\text { Yüzde } \\
(\%)\end{array}$ & $\begin{array}{l}\text { Gecerli } \\
\text { Yüzde(\%) }\end{array}$ \\
\hline a & 3 & 7,1 & 7,5 \\
\hline b & 7 & 16,7 & 17,5 \\
\hline c & 26 & 61,9 & 65 \\
\hline d & 4 & 9,5 & 10 \\
\hline Toplam & 40 & 95,2 & 100 \\
\hline Kayıp & 2 & 4,8 & \\
\hline Toplam & 42 & 100 & \\
\hline
\end{tabular}

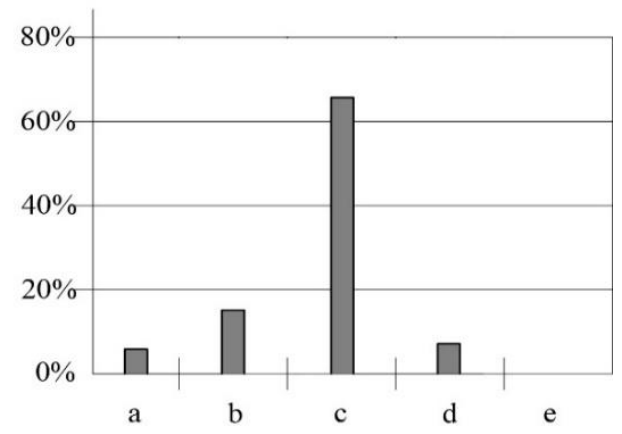

Grafik 10. Simetri ekseni sayıs 


\section{Bilgi Bütünleştiren Soruların Değerlendirmesi}

Bilgi bütünleştiren soru olarak iki adet soru sorulmuştur. Bu sorular ile öğrencilerin alan çalısması sırasında kullandıkları bilgileri aldıkları eğitimle ve mimari deneyimleriyle ilişkilendirmeleri hedeflenmiştir.

"Bu atölyede kullanılan çokyüzlülerin mimarlıkta nerelerde kullanıldığını düşünüyorsunuz?” sorusuna verilen cevaplar incelendiğinde; öğrencilerin, \%00,2'sinin uzay kafes sistemler, \%14,6'sının pünomatik sistemler, \%36,6'sının geniş açılklk geçmek için, \%34,1'inin toplu konutlarda, $\% 53,7$ 'sinin yapı malzeme modülü olarak, \%43,9'unun parametrik tasarım, \%80,5'inin eğitimde üç boyut alg1sı geliştirmede, \%36,6'sının detay birleşim noktalarında, \%63,4'ünün stant tasarımlarında, \%65,9'unun dekoratif öğelerde, \%56,1'inin herhangi bir boşluğu tanımlamakta, \%4,9'unun diğer cevabını verdiği tespit edilmiştir (Tablo 4).

Tablo 4. Çokyüzlülerin Mimarlıkta Kullanıldığı Alanlar

\begin{tabular}{|l|l|l|}
\hline \multirow{2}{*}{ Seçenekler } & Yanıtlar \\
\cline { 2 - 3 } & $\mathrm{N}$ & Yüzde (\%) \\
\hline Uzay kafes sistemler & 37 & 90,2 \\
\hline Pünomatik sistemler & 6 & 14,6 \\
\hline Geniş açıklık geçmek için & 15 & 36,6 \\
\hline Toplu konutlarda & 14 & 34,1 \\
\hline Yapı malzeme modülü olarak & 22 & 53,7 \\
\hline Parametrik tasarım & 18 & 43,9 \\
\hline Ĕgitimde üç boyut algısı geliştirmede & 33 & 80,5 \\
\hline Detay birleşim noktalarında & 15 & 36,6 \\
\hline Stant tasarımlarında & 26 & 63,4 \\
\hline Dekoratif ögelerde & 27 & 65,9 \\
\hline Herhangi bir boşluğu tanımlamakta & 23 & 56,1 \\
\hline Diğer? & 2 & 4,9 \\
\hline
\end{tabular}

“Atölyede kullanılan temel tasarım ilke ve elemanları" sorusuna verilen cevaplar incelendiğinde; öğrencilerin, $\% 90$ 'nnın tekrar, $\% 80$ 'inin uyum, $\% 85$ 'inin doluluk-boşluk, $\% 75$ 'inin yüzey oluşturma, \%80’inin hacim oluşturma kavramlarını seçtikleri tespit edilmiştir (Tablo 5). 
Tablo 5. Atölyede Kullanılan Temel Tasarım İlke ve Elemanları

\begin{tabular}{|l|l|l|}
\hline \multirow{2}{*}{ Seçenekler } & \multicolumn{2}{|l|}{ Yanıtlar } \\
\cline { 2 - 3 } & N & Yüzde (\%) \\
\hline Birlik & 27 & 67,5 \\
\hline Tekrar & 36 & 90,0 \\
\hline Simetri & 22 & 55,0 \\
\hline Denge & 27 & 67,5 \\
\hline Zitllk & 9 & 22,5 \\
\hline Uyum & 32 & 80,0 \\
\hline Doluluk-boşluk & 34 & 85,0 \\
\hline Ölçek-oran & 12 & 30,0 \\
\hline Doku oluşturma & 20 & 50,0 \\
\hline Yüzey oluşturma & 30 & 75,0 \\
\hline Hacim oluşturma & 32 & 80,0 \\
\hline Diğer & 4 & 10,0 \\
\hline
\end{tabular}

\section{Kazanım Ölçen Soruların Değerlendirmesi}

Kazanım ölçen sorular kendi içerisinde üç kategoride değerlendirilmiştir. Bunlar, bireysel kazanımlar, grup çalışması kazanımları ve tasarım modüllerine ilişkin kazanımlardır.

Bireysel kazanım; Ankete katılan öğrenciler, en yüksek oranda edindikleri kazanımlar olarak, \%82,9 oranında şekil uzay algısı gelişimi, \%92,7 oranında üç boyutlu düşünme becerisi, \%05,1 oranında yaparken öğrenmeyi belirtmişlerdir. En düşük olarak da \%39 oranında özgüven ve karar verme yetisini kullanma kazanımını belirtmişlerdir (Tablo 6).

\section{Tablo 6. Alan Çalışması Sürecinde Bireysel Kazanımlar}

\begin{tabular}{|l|l|l|}
\hline \multirow{2}{*}{ Bireysel kazanımlar } & \multicolumn{2}{l|}{ Yanıtlar } \\
\cline { 2 - 3 } & $\mathrm{N}$ & Yüzdelik (\%) \\
\hline Şekil uzay alğsı gelişimi & 34 & 82,9 \\
\hline Üç boyutlu düşünme becerisi & 38 & 92,7 \\
\hline Tasarlanabilir boşluğun geometrik düzeninin farkındalı̆̆1 & 23 & 56,1 \\
\hline Lisans öncesi geometri bilgisinin mimarlıktaki uzantısını görme & 19 & 46,3 \\
\hline Malzeme kullanımını deneyimleme & 18 & 43,9 \\
\hline Kesme biçimlerini deneyimleme & 28 & 68,3 \\
\hline Katlama biçimlerini deneyimleme & 25 & 61,0 \\
\hline Hacim oluşturma biçimlerini deneyimleme & 30 & 73,2 \\
\hline Dik açılı olmayan bir geometrik cismin görünüşlerini çizme & 23 & 56,1 \\
\hline Özgüven ve karar verme yetisini kullanma & 16 & 39,0 \\
\hline Deneyip yanılma şansina sahip olmak & 30 & 73,2 \\
\hline Yaparken öğrenme & 39 & 95,1 \\
\hline
\end{tabular}

Grup çalısması kazanımı; Ankete katılan öğrenciler, en yüksek oranda edinilen kazanımlar olarak, \%87,2 oranında iş bölümü deneyimlemek, \%84,6 oranında birlikte karar verme deneyimi yaşamak, 
\% 79,5 oranında tartışma, fikir alışverişi ortamında öğrenmeyi belirtmişlerdir. En düşük olarak da $\% 41$ oranında planlayarak yapma deneyimini belirtmişlerdir (Tablo 7).

\section{Tablo 7. Alan Çalışması Grup Çalışması Kazanımları}

\begin{tabular}{|l|l|l|}
\hline \multirow{2}{*}{ Grup çalışması kazanımı } & \multicolumn{2}{|l|}{ Yanıtlar } \\
\cline { 2 - 3 } & $\mathrm{N}$ & \multicolumn{1}{l|}{ Yüzdelik (\%) } \\
\hline İş bölümü deneyimlemek & 34 & 87,2 \\
\hline Birlikte karar verme deneyimi yaşamak & 33 & 84,6 \\
\hline Tartışma, fikir alışverişi ortamında öğrenmek & 31 & 79,5 \\
\hline Ortak bir başarıyı paylaşmak & 23 & 59,0 \\
\hline Ortak bir başarısızlığın sebebini tespit etmek & 22 & 56,4 \\
\hline Topluluk içerisinde karar verme ve fikrini izah etme deneyimi & 26 & 66,7 \\
\hline Planlayarak yapma deneyimi & 16 & 41,0 \\
\hline Yaparken planlama deneyimi & 28 & 71,8 \\
\hline Kolektif bir çalışmanın parçası olmak & 26 & 66,7 \\
\hline Katılım esaslı bir uygulamanın deneyimlenmesi & 30 & 76,9 \\
\hline
\end{tabular}

Tasarım modülleri hakkındaki kazanımlar, Ankete katılan öğrenciler, en yüksek oranda edinilen kazanımlar olarak, \%82,1 oranında düzgün dört yüzlünün kenar, köşe ve yüzey sayılarının kavranması, \% 79,5 oranında küpün kenar, köşe ve yüzey sayılarının kavranması, \%69,2 oranında bazı polihedronların kenarlarından bazılarınınsa yüzeylerinden temasla paketlendiğinin deneyimlenmesi ve yine aynı oranda atomların bağ yapısının geometrisinde görülmesi olduğunu belirtmişlerdir. En düşük olarak da \%51,3 oranında düzgün yirmi yüzlünün kenar, köşe ve yüzey sayılarının kavranmasını belirtmişlerdir (Tablo 8).

Tablo 8. Alan çalışması tasarım modülleri hakkındaki kazanımlar

\begin{tabular}{|l|l|l|}
\hline Tasarım modülleri hakkındaki kazanımlar & \multicolumn{2}{l|}{ Yanıtlar } \\
\cline { 2 - 3 } & $\mathrm{N}$ & \multicolumn{2}{l|}{ Yüzdelik (\%) } \\
\hline Düzgün dörtyüzlünün kenar, köşe ve yüzey sayılarının kavranması & 32 & 82,1 \\
\hline Düzgün sekizyüzlünün kenar, köşe ve yüzey sayılarının kavranması & 22 & 56,4 \\
\hline Düzgün onikiyüzlünün kenar, köşe ve yüzey sayılarının kavranması & 21 & 53,8 \\
\hline Düzgün yirmiyüzlünün kenar, köşe ve yüzey sayılarının kavranması & 20 & 51,3 \\
\hline Küp ün uzayda boşluksuz paketlendiğinin kavranması & 26 & 66,7 \\
\hline $\begin{array}{l}\text { Bazı polihedronların kenarlarından bazılarınınsa yüzeylerinden temasla } \\
\text { paketlendiğinin deneyimlenmesi }\end{array}$ & 27 & 69,2 \\
\hline Küpün kenar, köşe ve yüzey sayılarının kavranması & 31 & 79,5 \\
\hline $\begin{array}{l}\text { Düzgün çokyüzlülerin doğada bulunan katıl kristal yapıların temel modülleri } \\
\text { olması. }\end{array}$ & 24 & 61,5 \\
\hline Atomların bağ yapısının geometrisinde görülmesi & 27 & 69,2 \\
\hline Doğada bulunan altın oranın bazı polihedronların geometrisinde bulunması & 26 & 66,7 \\
\hline
\end{tabular}

Katılımcı 42 öğrenciden "Benzer atölye çalışmalarında aktif olarak yer almak ister misiniz?" sorusuna 27 kişi evet cevabını vermiştir. Evet seçeneğini işaretleyen öğrencilerin atölye sürecinde 
"yaparken öğrendiklerinizi” işaretleyiniz bölümde bireysel kazanımlardan en yüksek oranda, $(\% 96,3)$ üç boyutlu düşünme becerisi, $(\% 96,3)$ yaparken öğrenme, $(\% 92,6)$ şekil alg1s1 gelişimi, $(\% 77,8)$ kesme biçimlerini deneyimleme, $(\% 77,8)$ deneyip yanılma şansına sahip olma seçeneklerini işaretledikleri tespit edilmiştir (Tablo 9).

Tablo 9. Atölye Sürecinde Bireysel Kazanımlar

\begin{tabular}{|c|c|c|c|}
\hline & & & Evet \\
\hline \multirow{24}{*}{$\begin{array}{l}\text { Bireysel } \\
\text { Kazanım }\end{array}$} & \multirow[t]{2}{*}{ Şekil uzay algısı gelişimi } & Say1 & 25 \\
\hline & & Yüzde $(\%)$ & 92,6 \\
\hline & \multirow[t]{2}{*}{ Üç boyutlu düşünme becerisi } & Say1 & 26 \\
\hline & & Yüzde (\%) & 96,3 \\
\hline & \multirow[t]{2}{*}{ Tasarlanabilir boşluğun geometrik düzeninin farkındalığ1 } & Say1 & 20 \\
\hline & & Yüzde (\%) & 74,1 \\
\hline & \multirow{2}{*}{$\begin{array}{l}\text { Lisans öncesi geometri bilgisinin mimarlıktaki uzantısını } \\
\text { görme }\end{array}$} & Say1 & 16 \\
\hline & & Yüzde $(\%)$ & 59,3 \\
\hline & \multirow[t]{2}{*}{ Malzeme kullanımını deneyimleme } & Say1 & 15 \\
\hline & & Yüzde (\%) & 55,6 \\
\hline & \multirow[t]{2}{*}{ Kesme biçimlerini deneyimleme } & Say1 & 21 \\
\hline & & Yüzde (\%) & 77,8 \\
\hline & \multirow[t]{2}{*}{ Katlama biçimlerini deneyimleme } & Say1 & 17 \\
\hline & & Yüzde $(\%)$ & 63,0 \\
\hline & \multirow[t]{2}{*}{ Hacim oluşturma biçimlerini deneyimleme } & Say1 & 20 \\
\hline & & Yüzde (\%) & 74,1 \\
\hline & \multirow{2}{*}{$\begin{array}{l}\text { Dik açılı olmayan bir geometrik cismin görünüşlerini } \\
\text { çizme }\end{array}$} & Say1 & 18 \\
\hline & & Yüzde $(\%)$ & 66,7 \\
\hline & \multirow[t]{2}{*}{ Özgüven ve karar verme yetisini kullanma } & Say1 & 10 \\
\hline & & Yüzde $(\%)$ & 37,0 \\
\hline & \multirow[t]{2}{*}{ Deneyip yanılma şansına sahip olmak } & Say1 & 21 \\
\hline & & Yüzde $(\%)$ & 77,8 \\
\hline & \multirow[t]{2}{*}{ Yaparken öğrenme } & Say1 & 26 \\
\hline & & Yüzde $(\%)$ & 96,3 \\
\hline \multirow{2}{*}{\multicolumn{2}{|c|}{ Toplam }} & Say1 & Say1 \\
\hline & & Yüzde (\%) & 100,0 \\
\hline
\end{tabular}

"Benzer atölye çalışmalarında aktif olarak yer almak ister misiniz?” sorusuna 27 kişi evet cevabını vermiştir. Evet seçeneğini işaretleyen öğrencilerin atölye sürecinde "yaparken öğrendiklerinizi” işaretleyiniz bölümde grup çalışması kazanımında en yüksek oranda, $(\% 96,3)$ iş bölümü deneyimlemek, $(\% 92,6)$ katılım esaslı bir uygulamanın deneyimlenmesi, $(\% 88,9)$ tartışma, fikir alışverişi ortamında öğrenmek, $(\% 85,2)$ birlikte karar verme deneyimi yaşamak, $(\% 77,8)$ kolektif bir çalışmanın parçası olma seçeneklerini işaretledikleri tespit edilmiştir (Tablo 10). 
Tablo 10. Atölye Sürecinde Grup Çalışması Kazanımları

\begin{tabular}{|c|c|c|c|}
\hline \multirow{4}{*}{$\begin{array}{l}\text { Grup } \\
\text { çalışması } \\
\text { kazanımı }\end{array}$} & & & Evet \\
\hline & \multirow[t]{2}{*}{ İş bölümü deneyimlemek } & Say1 & 26 \\
\hline & & Yüzde $(\%)$ & 96,3 \\
\hline & \multirow[t]{2}{*}{ Birlikte karar verme deneyimi yaşamak } & Say1 & 23 \\
\hline & & Yüzde $(\%)$ & 85,2 \\
\hline & \multirow[t]{2}{*}{ Tartışma, fikir alışverişi ortamında öğrenmek } & Say1 & 24 \\
\hline & & Yüzde $(\%)$ & 88,9 \\
\hline & \multirow[t]{2}{*}{ Ortak bir başarıyı paylaşmak } & Say1 & 20 \\
\hline & & Yüzde $(\%)$ & 74,1 \\
\hline & \multirow[t]{2}{*}{ Ortak bir başarısızlığın sebebini tespit etmek } & Say1 & 19 \\
\hline & & Yüzde $(\%)$ & 70,4 \\
\hline & \multirow{2}{*}{$\begin{array}{l}\text { Topluluk içerisinde karar verme ve fikrini izah etme } \\
\text { deneyimi }\end{array}$} & Say1 & 21 \\
\hline & & Yüzde $(\%)$ & 77,8 \\
\hline & \multirow[t]{2}{*}{ Planlayarak yapma deneyimi } & Say1 & 11 \\
\hline & & Yüzde $(\%)$ & 40,7 \\
\hline & \multirow[t]{2}{*}{ Yaparken planlama deneyimi } & Say1 & 20 \\
\hline & & Yüzde $(\%)$ & 74,1 \\
\hline & \multirow[t]{2}{*}{ Kolektif bir çalışmanın parçası olmak } & Say1 & 21 \\
\hline & & Yüzde $(\%)$ & 77,8 \\
\hline & \multirow[t]{2}{*}{ Katılım esaslı bir uygulamanın deneyimlenmesi } & Say1 & 25 \\
\hline & & Yüzde $(\%)$ & 92,6 \\
\hline \multirow{2}{*}{\multicolumn{2}{|c|}{ Toplam }} & Say1 & 27 \\
\hline & & Yüzde $(\%)$ & 100,0 \\
\hline
\end{tabular}

"Benzer atölye çalışmalarında aktif olarak yer almak ister misiniz?” sorusuna Evet seçeneğini işaretleyen öğrencilerin atölye sürecinde "yaparken öğrendiklerinizi” işaretleyiniz bölümde tasarım modülleri hakkında en yüksek oranda, (\%81,5) Küpün kenar, köşe ve yüzey sayılarının kavranmas1, $(\% 77,8)$ Düzgün dörtyüzlünün kenar, köşe ve yüzey sayılarının kavranması, $(\% 74,1)$ atomların bağ yapısının geometrisinde görülmesi, $(\% 74,1)$ Doğada bulunan altın oranın bazı polihedronların geometrisinde bulunması, (\%70,4) Düzgün çokyüzlülerin doğada bulunan katıl kristal yapıların temel modülleri olması seçeneklerini işaretledikleri tespit edilmiştir (Tablo 11).

Anket sırasında kazanım sorularında öğrencilerin büyük bir çoğunluğu "yaparak öğrenme" deneyimi edindiklerini belirtmişlerdir. Öğrencilerin polihedron biçimlerle tasarım oluşturma sürecinde ellerindeki malzemenin dayanımına göre parçaların bütündeki yerini belirledikleri ve strüktürel denge kurmaya çalıştıkları gözlemlenmiştir.

Süreç içerisinde bir çizgiden, poligon çizimine ve poligon yüzeylerden oluşan üç boyutlu bir hacim tanımlayan polihedron nesnesine geçiş, hem çizim hem de maket aracıllı̆̆ ile deneyimlenmiştir. $\mathrm{Bu}$ bağlamda alan çalışmasının birbiri ardına gelen aşamalarının algoritmik düşünceye temel oluşturduğu söylenebilir. Yine aynı süreçte nesnenin oluşumunda kullanılan iki boyutlu ve üç boyutlu sayısal bilgi öğrencinin zihninde işlenmektedir. Bu sebeple alan çalışmasının öğrencinin zihninde matematiksel uzayın kavranmasına ve biçim algısının gelişmesine katkıda bulunduğu düşünülmektedir. 
Tablo 11. Atölye Sürecinde Tasarım Modülleri Hakkındaki Kazanımlar

\begin{tabular}{|c|c|c|c|}
\hline \multirow{3}{*}{\multicolumn{2}{|c|}{\begin{tabular}{l|l} 
Tasarım \\
modülleri
\end{tabular} $\begin{array}{l}\text { Düzgün dörtyüzlünün kenar, köşe ve yüzey sayılarının } \\
\text { kavranması }\end{array}$}} & & Evet \\
\hline & & Say1 & 21 \\
\hline & & Yüzde $(\%)$ & 77,8 \\
\hline \multirow[t]{18}{*}{ hakkinda } & \multirow{2}{*}{$\begin{array}{l}\text { Düzgün sekizyüzlünün kenar, köşe ve yüzey sayılarının } \\
\text { kavranması }\end{array}$} & Say1 & 16 \\
\hline & & Yüzde $(\%)$ & 59,3 \\
\hline & \multirow{2}{*}{$\begin{array}{l}\text { Düzgün on iki yüzlünün kenar, köşe ve yüzey sayılarının } \\
\text { kavranması }\end{array}$} & Say1 & 13 \\
\hline & & Yüzde $(\%)$ & 48,1 \\
\hline & \multirow{2}{*}{$\begin{array}{l}\text { Düzgün yirmi yüzlünün kenar, köşe ve yüzey sayılarının } \\
\text { kavranması }\end{array}$} & Say1 & 13 \\
\hline & & Yüzde $(\%)$ & 48,1 \\
\hline & \multirow[t]{2}{*}{ Küp ün uzayda boşluksuz paketlendiğinin kavranması } & Say1 & 16 \\
\hline & & Yüzde $(\%)$ & 59,3 \\
\hline & \multirow{2}{*}{$\begin{array}{l}\text { Bazı polihedronların kenarlarından bazılarınınsa } \\
\text { yüzeylerinden temasla paketlendiğinin deneyimlenmesi }\end{array}$} & Say1 & 18 \\
\hline & & Yüzde $(\%)$ & 66,7 \\
\hline & \multirow[t]{2}{*}{ Küpün kenar, köşe ve yüzey sayılarının kavranması } & Say1 & 22 \\
\hline & & Yüzde $(\%)$ & 81,5 \\
\hline & \multirow{2}{*}{$\begin{array}{l}\text { Düzgün çokyüzlülerin doğada bulunan katıl kristal } \\
\text { yapıların temel modülleri olması }\end{array}$} & Say1 & 19 \\
\hline & & Yüzde $(\%)$ & 70,4 \\
\hline & \multirow[t]{2}{*}{ Atomların bağ yapısının geometrisinde görülmesi } & Say1 & 20 \\
\hline & & Yüzde $(\%)$ & 74,1 \\
\hline & \multirow{2}{*}{$\begin{array}{l}\text { Doğada bulunan altın oranın bazı polihedronların } \\
\text { geometrisinde bulunması }\end{array}$} & Say1 & 20 \\
\hline & & Yüzde (\%) & 74,1 \\
\hline \multirow{2}{*}{\multicolumn{2}{|c|}{ Toplam }} & Say1 & 27 \\
\hline & & Yüzde $(\%)$ & 100,0 \\
\hline
\end{tabular}

Alan çalışması sırasında polihedron modüller ile tepe, kenar ve yüzeylerden birleştirilerek farklı örüntüler oluşturulmuştur. Küp dışındaki çalışılan bu çokyüzlü geometrilerin birleşim olasılıkları öğrenci tarafindan öngörülmediği için çalışma deneysel olarak ilerlemiştir.

\section{ÖNERİLER (SUGGESTIONS)}

Değişen, güncellenen tasarım yaklaşımları ve araçlarıyla birlikte biçimlendirme yöntemleri de değişmekte ve gelişmektedir. Bugün biçim geometrileri öklidyen dünyadan non- öklidyen dünyaya geçiş yapmakta ve dijital tasarım araçları hızlı, sistematik oluşlarıyla hesaplamalı biçimlendirme yöntemleri olarak karşımıza çıkmaktadır. Zaman akışının çok hızlı olduğu günümüzde Temel Tasarım eğitiminden itibaren birçok edinimi kısa zamanda verebilecek stüdyo yaklaşımları önemlidir. Bilgisayar ortamına geçmeden önce öğrencilerin kendi biçim ve işlev kavrayışlarını geliştirmeleri gerekmektedir. Bir taraftan geleneksel yöntemlerle bu kavrayış sağlanırken bir taraftan da hesaplamalı, parametrik tasarım yaklaşımlarının zemini kurulmalıdır.

Bu çalışma doğa-biçim, hesaplamalı tasarım, mimarlık temel eğitim uygulamaları gibi konular ele alınarak yapılmış deneysel bir çalışmadır. Benzer alan çalışmalarının daha uzun vadede çalışıldığı bir kurgu tasarlanarak, eğitim müfredatında yer almasının, öğrencinin geometri bilgisini, üç boyut algısını geliştirmede ve bilgisayar destekli tasarıma geçişte olumlu katkı sağlayacağı düşünülmektedir. 


\section{SONUÇ (CONCLUSION)}

Hesaplamalı tasarım, günümüzde dijital teknolojinin gelişmesi ile bilgisayar ortamında daha fazla uygulama olanağı bulmaktadır. Ancak hesaplamalı tasarımı, bilgisayar ortamında kullanılmakta olan mimari program bilgisi ve bu programlar ile tasarımın gerçekleştirilmesi olarak alg1lamamak gerekmektedir. Hesaplamalı tasarım, 1960'lardan itibaren gelişmiş bir tasarım yaklaşımıdır. Hesaplamalı tasarımın; yaparak öğrenme, deneme yanılma, aynı anda birçok şeyi düşünme ve tasarımın gerekçelendirilmesi gibi temellere dayandığ1 görülmektedir. Bu bağlamda, hesaplamalı tasarım, geleneksel temel tasarım eğitiminde geometri-biçim bilgisi ve geometriye dayalı biçimlenmede matematiksel ilişkilere dayalı tasarım yaklaşımı olarak düşünülebilir.

Yapılan deneysel çalışma, bir taraftan parçadan bütüne giden kendi içerisinde bir mantığı olan, parçalar arasındaki ilişkinin türeyebilmeye, değişime ve özgürleşmeye imkan veren, matematiksel kazanımları elde etmeye yönelik bir çalışma olması sebebiyle hesaplamalı yaklaşıma alt yapı sağlamakta, diğer taraftan doğal ve yapay biçimlendirme ilkelerini kullanma, malzeme deneyimi, yaparak öğrenme, estetik, işlevsel ve bağlamsal tüm kazanımları sağlaması yönüyle de geleneksel yaklaşımı yansıtmaktadır. Bu açıdan çalışmanın başında soru olarak ifade edilen "üç boyutlu biçim bilgisini geliştirmek için izlenecek bir yöntemle geleneksel eğitim modeliyle hesaplamalı tasarım yaklaşımını birleştirme" nin mümkün olabileceği görülmüştür.

Alan çalışmasında seçilen polihedronların; hem doğal biçimlenme, hem de yapay biçimlenme örneklerinde incelenme şansının oluşu, aynı zamanda hesaplamalı yaklaşımlarda, dijital ortamda başlangıç seviyesinde kullanılmasından dolayı bu çalışma kapsamında uygun bir tasarım nesnesi olarak belirlenmiştir.

Üç boyutlu düşünme ve biçim bilgisi, zihinde üç boyutlu bir dünya oluşturabilmeyi gerektirir. Dijital araçların kullanımının dezavantajlarından biri insan beynini pasifleştirmesidir. Günümüzde düzgün poligonlar gibi temel geometrilerin çizimleri bile, gönye pergel yardımıla, temel geometri bilgisi ile öğrenciler tarafından çizilemez hale gelmektedir. Hâlbuki zihindeki matematiksel uzayın gelişimi ve üç boyut algisının artması için eskiz yapma ve temel geometrilere hâkim olma becerileri gerekmektedir. Bunun için yaşanılan doğanın matematiksel düzeninin içerisinden bir kavramsal nesne seçilerek soyutlanması, teknik çizim ifadesi için hesaplamalı, sıralamalı çizim yöntemlerinin uygulanması, iki boyutlu biçimsel altyapısının kavranması aşamalarından sonra üçüncü boyutta modellenmesi ve bir tasarım nesnesi haline gelmesi aşamalarıla zihinde biçimlerin parçadan bütüne yer edinmesi hedeflenmiştir. Sonuç ürünler ve anket sonuçlarına göre çalışma bir biçimlendirme yöntemi olarak ve hesaplamalı tasarımın temel kazanımlarını sağlaması bakımından büyük oranda başarı sağlamıştır. Yine anket verilerine göre yaparak öğrenme ile polihedronların geometrik bilgisinin kavranmasının öğrencilerin üç boyutlu biçim algısını geliştirdiği açıkça görülmektedir. 


\section{REFERANSLAR (REFERENCES)}

Armstrong, T. (2009). Multiple intelligences in the classroom (3rd. Ed.). Alexandra, Usa: ASCD Publishing, ss:68-112

Ataseven, O. (2011) Oluşum süreci içinde türk heykel sanatına ilişkin kısa bir değerlendirme Türk Sanatlar Arastırmalar Dergisi, 1(2), ss:74

Beşlioğlu, B. (2013). Türkiyede hesaplamalı tasarım kültürü:1950-1980, Doktora Tezi, Yıldız Teknik Üniversitesi, İstanbul, ss:88-95

Gausa, M., Guallart, V., Müller, W., Soriano, F, Porras, F. \& Morales, J. (2003). The Metapolis Dictionary of Advanced Architecture: City, Technology and Society in the Information Age. Barcelona: Ingoprint SA., ss:47

Hançerlioğlu, O. (2010). Düs̈̈̈nce Taribi, İstanbul, Remzi Kitabevi, ss:269-312

Karakırık, E. (2011). Dinamik geometri ve Sketchpad ile geometri ögretimi. Matematik eğitiminde teknoloji kullanım içinde. Ankara. Nobel Yayın Dağıtım, ss:125

Koman, $\dot{\mathrm{I}}$. (1983). " $\pi+\pi+\pi+\pi+\cdots$ ", yayınlanmamış metin, İlhan Koman Vakfı Arşivi, ss:78

Stevens, G.(1990). The reasoning architect mathematics and science in design. Singapore: Mc Graw Hill Publishing company, ss:112

Sunagawa, I. (2005). Crystals, growth morphology and perfection. New York: Cambridge University Press, ss:66

Şahinler, O., Kızıl, F. (2014). Mimarlkta teknik resim (12.Bask1). İstanbul: Yap1-Endüstri Merkezi Yayınlar1, ss:144

Yalınay Çinici, Ş. (2012). Computation, çevirisi ve anlaması kolay olmayan dil, Düs̆̈̈nce Ve Mimarlı.. Dosya, 29, TMMOB Ankara Şubesi, ss:25

Yurtsever, H. (2008). Uygulamal Estetik. Ankara: Art Basın Yayın, ss:55-152

\section{İnternet Kaynakları}

URL 1: https://www.cse.buffalo.edu/ rapaport/584/computetymology.html (E.T. 11.12.2017)

URL 2: https://www.thefreedictionary.com/compute (E.T. 10.12.2017)

URL 3: https:/ / nazmimetin.wordpress.com/sanat/turk-da-vincisi-ilhan-komanin-eserleri-vehayati/ (E.T. 09.01.2020)

URL 4: https://twitter.com/scaramouchmor/status/814865011948527616 (E.T. 09.01.2020)

URL 5: http://tabletopwhale.com/page11/ (E.T. 02.11.2017)

URL 6: http://www.zvihecker.com/projects/ramot_housing-113-1.html\#18 (E.T. 09.01.2020) 


\section{YAZARLARIN BİYOGRAFİSİ (BIOGRAPHY OF THE AUTHORS)}

\section{Rabia AKGÜL}

1986 İstanbul doğumludur. Lise eğitimini Uşak Fen Lisesinde tamamlamış, 2009 yılında Karabük Üniversitesi Fethi Toker Güzel sanatlar ve Tasarım Fakültesi, Mimarlık Bölümünden mezun olmuştur. 2015 yllından bu yana Dokuz Eylül Üniversitesi Mimarlık Fakültesi, Mimarlık Bölümünde Araştırma Görevlisi olarak çalışmaktadır. "Mimarlık Temel Eğitiminde Polihedronların Üç Boyutlu Biçimlendirmeye Etkileri Üzerine Deneysel Bir Çalışma” adlı yüksek lisans tezini Dokuz Eylül Üniversitesi Bina Bilgisi alanında tamamlayarak, yine aynı üniversitede, Mimarlık Eğitiminde Kinetik tasarım Uygulamaları üzerine doktora çalışmalarını sürdürmektedir.

\section{Hasan BEGEÇ, Dr.}

1996 yllında Dokuz Eylül Üniversitesi Mimarlık Fakültesi Mimarlık Bölümü’nden mezun oldu. 1999 yılında "Çok Katlı Büro Binalarının Gelişiminin Biçimlenme Özellikleri Açısından Değerlendirilmesi”, isimli tez çalışması ile yüksek lisans, 2005 yılında "İletişim Teknolojilerinin Büro Mekânlarına Etkileri ve Medya Yapılarında Yeni Mekân Kullanım Biçimlerinin Uygulanabilirliği’, isimli tez çalışması ile doktora derecesini aldı. Akademik çalışmalarında; Yüksek yapılar, yüksek yapı planlama ve tasarımı, yüksek yapılarda kullanılan taşıyıcı sistemler, yüksek yapı servis sistemleri, büro yapıları, büro mekân organizasyonu alanları ile ilgilenmektedir. Şu an Dokuz Eylül Üniversitesi Mimarlık Fakültesi Mimarlık Bölümü Bina Bilgisi Anabilim Dalı’nda Doktor Öğretim Üyesi olarak görev yapmaktadır. 